\title{
Indexes of performance of combustion engines in hybrid vehicles during the UDC test
}

\begin{abstract}
An increased interest in hybrid drive systems allowing reduction of fuel consumption and emissions of harmful substances into the atmosphere, as well as their partial use as zero-emission vehicles promotes the development of these types of drive systems. The market analysis indicates an increased sale of hybrid drives in vehicles, and this means that actions taken towards of reduction of fuel consumption are still valid. The aim of this article is to indicate the indexes of performance of combustion engines in hybrid vehicles during a part of the type-approval driving test. The article analyses Toyota hybrid vehicles with particular attention paid to the parameters of the hybrid drive system and the influence of the charge level of battery on the share of the combustion engine operation in the total time of the vehicle operation. The analysis was carried out for vehicles equipped with the Toyota Hybrid Synergy Drive system working with different types of high voltage battery.
\end{abstract}

Key words: hybrid drive systems, combustion engine, electric motor, UDC drive test, energy recovery

\section{Użytkowe wskaźniki pracy silników spalinowych w pojazdach hybrydowych podezas testu UDC}

\begin{abstract}
Zwiększone zainteresowanie układami napędu hybrydowego, które pozwalają na zmniejszenie zużycia paliwa, emisji sktadników szkodliwych do atmosfery, a także częściowe ich wykorzystanie jako pojazdów zeroemisyjnych skłania do rozwoju tych jednostek. Analizy rynkowe wykazuja zwiększenie sprzedaży tych układów napędowych w pojazdach, co oznacza aktualność działań podejmowanych w celu zmniejszenia zużycia paliwa. Założeniem artykułu jest wykazanie użytkowych wskaźników pracy silnika spalinowego w pojazdach hybrydowych podczas części homologacyjnego testu jezdnego. Dokonano analizy pojazdów hybrydowych firmy Toyota ze szczególnym uwzględnieniem parametrów układu napędu hybrydowego oraz wpływu stopnia naładowania akumulatorów na udziat silnika spalinowego w ogólnym czasie pracy pojazdu. Analizy przeprowadzono dla pojazdów wyposażonych w system napędowy Toyota Hybrid Synergy Drive wspótpracujący z różnymi rodzajami akumulatorów wysokonapięciowych.

Słowa kluczowe: układy napędu hybrydowego, silnik spalinowy, silnik elektryczny, test jezdny UDC, odzyskiwanie energii
\end{abstract}

\section{Introduction and justification of the subject of the research}

Contemporary development of driving systems in vehicles involves the need to take into account often contradictory requirements concerning - on one hand - the environment protection by reducing emissions of harmful components of exhaust gases into the atmosphere, and - on the other hand - the need to obtain maximum performance parameters for these drive systems. Continuous reduction of the emissions of carbon dioxide $\left(\mathrm{CO}_{2}\right)$ limits promotes the search for new solutions of drive systems, enabling partial or total replacement of the combustion engine $[8,9,10]$ according to the strategy of the share of drive systems shown in Fig. 1.

The analysis of the increase of the share of hybrid drive systems in population of all drive systems indicates significant potential for development of these drive systems (Fig. 2). This is a particularly important segment of vehicle market in the North America, however, the European market has also a significant share in the sale of such drive systems. The analysis conducted by the JDPower consulting company [5] indicates that the share of the vehicles with hybrid drive systems (HV - hybrid vehicle) in the market will increase from $2.2 \%$ in 2010 to $7.3 \%$ in 2020 .

\section{Wprowadzenie i uzasadnienie tematyki badań}

Obecny rozwój układów napędowych pojazdów związany jest z koniecznością uwzględniania często sprzecznych wymagań, które dotyczą - z jednej strony - ochrony środowiska przez ograniczanie emisji szkodliwych składników spalin do atmosfery, a z drugiej - dążenia do uzyskiwania maksymalnych wskaźników pracy tych jednostek. Ciągłe ograniczanie emisji dwutlenku węgla $\left(\mathrm{CO}_{2}\right)$ skłania do poszukiwania nowych rozwiązań układów napędowych, umożliwiających częściowe lub całkowite zastąpienie silnika spalinowego $[8,9,10]$, zgodnie z przedstawioną na rys. 1 strategią udziału napędów.

Wzrost udziału układów napędu hybrydowego w populacji wszystkich układów napędowych wskazuje na istnienie znacznego potencjału rozwojowego tych konstrukcji (rys. 2). Jest to szczególnie ważny segment rynku pojazdów w Ameryce Północnej, jednak rynek europejski ma także duży udział w sprzedaży tych napędów. Analiza firmy konsultingowej JDPower [5] wskazuje, że udział pojazdów z układami napędu hybrydowego (HV - hybrid vehicle) na rynku zwiększy się z 2,2\% w 2010 roku do 7,3\% w 2020 roku.

Stosowanie układów napędu hybrydowego w pojazdach umożliwiło firmie Toyota uzyskanie w 2012 roku średniej emisji drogowej $\mathrm{CO}_{2}$ na poziomie $122 \mathrm{~g} / \mathrm{km}$. Firma ta 


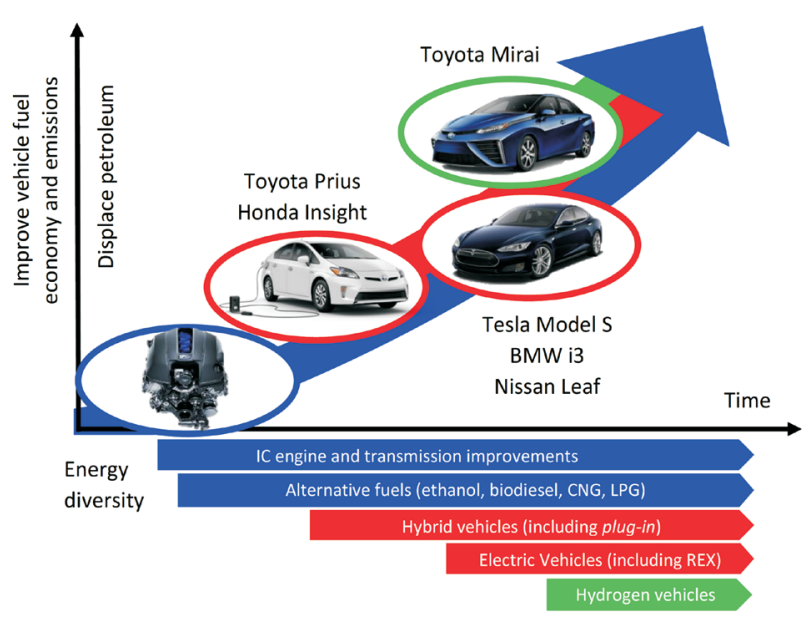

Fig. 1. Advanced propulsion technology strategy [7, 14] Rys. 1. Strategia rozwoju układów napędowych pojazdów [7, 14] ma obecnie największy udział pojazdów we flocie $(23 \%)$ $\mathrm{z}$ emisją drogową $\mathrm{CO}_{2}$ poniżej $100 \mathrm{~g} / \mathrm{km}$ (modelami firmy są: iQ $-99 \mathrm{~g} / \mathrm{km}$, Aygo $-99 \mathrm{~g} / \mathrm{km}$, Yaris Hybrid $-79 \mathrm{~g} / \mathrm{km}$, Auris - $99 \mathrm{~g} / \mathrm{km}$, Auris Hybrid $-84 \mathrm{~g} / \mathrm{km}$, Auris Hybrid Touring Sports $-85 \mathrm{~g} / \mathrm{km}$, Prius $-89 \mathrm{~g} / \mathrm{km}$, Prius +-96 $\mathrm{g} / \mathrm{km}$, Prius plug-in Hybrid $-49 \mathrm{~g} / \mathrm{km}$, Lexus CT $200 \mathrm{~h}-87$ $\mathrm{g} / \mathrm{km}$ oraz Lexus IS $300 \mathrm{~h}-99 \mathrm{~g} / \mathrm{km}$ ).

\section{Kierunki badań układów napędu hybrydowego}

Badania eksploatacyjne układów napędu hybrydowego prowadzone są od początku ich rozwoju. Obecnie duży nacisk jest położony na współpracę silnika spalinowego i elektrycznego, ze szczególnym uwzględnieniem znacznego udziału pracy silnika elektrycznego w całkowitym czasie pracy układu napędu hybrydowego.

Podjęte przez autorów artykułu badania są kontynuacją badań dotyczących analizy wskaźników eksploatacyjnych pojazdów hybrydowych $[3,10]$, wpływu naładowania aku-

Application of hybrid drives in vehicles enabled Toyota company to obtain in 2012 the average road emissions of $\mathrm{CO}_{2}$ at a level of $122 \mathrm{~g} / \mathrm{km}$. This company has currently the largest share of vehicles in the fleet $(23 \%)$ with the road emission of carbon dioxide below $100 \mathrm{~g} / \mathrm{km}$ (these models are: $\mathrm{iQ}-99$ $\mathrm{g} / \mathrm{km}$, Aygo - $99 \mathrm{~g} / \mathrm{km}$, Yaris Hybrid - 79 $\mathrm{g} / \mathrm{km}$, Auris - $99 \mathrm{~g} / \mathrm{km}$, Auris Hybrid $84 \mathrm{~g} / \mathrm{km}$, Auris Hybrid Touring Sports $-85 \mathrm{~g} / \mathrm{km}$, Prius $-89 \mathrm{~g} / \mathrm{km}$, Prius +-96 $\mathrm{g} / \mathrm{km}$, Prius plug-in Hybrid $-49 \mathrm{~g} / \mathrm{km}$, Lexus CT $200 \mathrm{~h}-87 \mathrm{~g} / \mathrm{km}$ and Lexus IS $300 \mathrm{~h}-99 \mathrm{~g} / \mathrm{km}$ ).

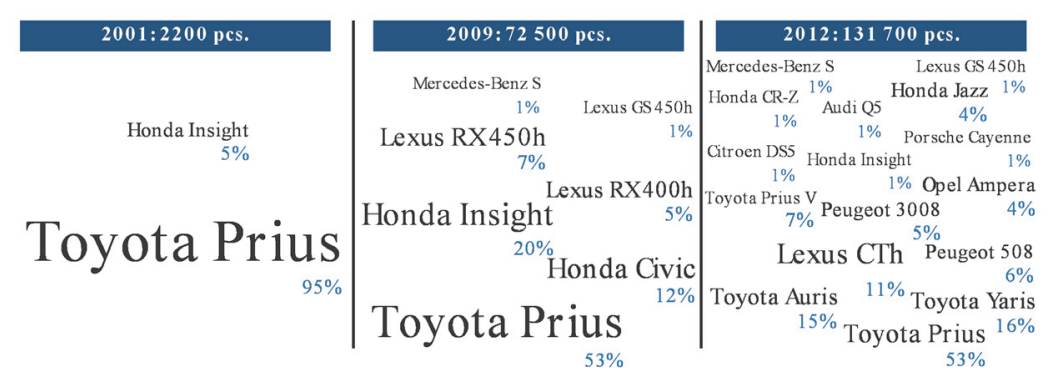

Fig. 2. Major manufacturers of hybrid drive systems in the European market [4] Rys. 2. Główni producenci pojazdów hybrydowych na rynku europejskim [4]

\section{Directions of research on the hybrid drives}

The performance tests of the hybrid drive systems have been carried out since the beginning of their development. Currently a large emphasis is put on the co-operation of the combustion engine with the electric motor with particular attention paid to the significant share of the electric motor operation in total operation time of the hybrid drive system.

The research undertaken by the authors is a continuation of the subject concerning the analysis of the performance parameters of the hybrid drive systems $[3,10]$, the analysis of the influence of the charge level of battery on the operational conditions of these hybrid drive systems in the NEDC test [11] and the thermodynamic conditions of the combustion engine cooperating with the electric motor [2]. Currently carried out analysis concern the conditions of the hybrid drive system operation during the first part of the NEDC (New European Driving Cycle) test: driving in urban conditions (UDC test - urban driving cycle). These tests involved the latest designs of Toyota hybrid vehicles.

\section{Hybrid Drives Development}

The story of the sales of the mass-produced hybrid car by Toyota begins in 1997, when such propulsion was introduced into the market in Japan. In the first year 300 vehicles were sold, and a year later -18 thousand. In 1999 there was mulatorów na warunki pracy ukłądu napędu hybrydowego w teście NEDC [11] oraz termodynamicznych warunków pracy silnika spalinowego współpracującego z silnikiem elektrycznym [2]. Obecnie prowadzone badania dotyczą warunków pracy układu napędu hybrydowego podczas pierwszej części testu NEDC (new european driving cycle), czyli w teście miejskim UDC (urban driving cycle). Badania te związane są z najnowszymi konstrukcjami pojazdów hybrydowych firmy Toyota.

\section{Rozwój układów napędu hybrydowego}

Historia sprzedaży seryjnie produkowanych pojazdów hybrydowych przez firmę Toyota rozpoczęła się w 1997 roku, gdy takie pojazdy wprowadzono do sprzedaży w Japonii. W pierwszym roku sprzedano 300 pojazdów, a rok później - 18 tys. sztuk. W roku 1999 nastąpił wzrost sprzedaży prawie o $100 \%$ - do ponad 33 tys. sztuk.

Sprzedaż pojazdów Toyota Prius w Stanach Zjednoczonych rozpoczęła się w 2000 roku, jednak po zdobyciu nagrody Samochodu Roku na tym rynku w 2004 roku sprzedaż zwiększyła się z 36 tys. (2003 r.) do 47 tys., a okres oczekiwania na samochód wynosił do 6 miesięcy.

W roku 2007 w USA sprzedano ponad 180 tys. pojazdów Toyoty Prius, natomiast $\mathrm{w}$ następnym roku -20 tys. miesięcznie. Do sukcesu sprzedaży modelu Prius na tym największym (poza Japonią) rynku przyczyniła się nota 
nearly $100 \%$ increase in the sale - up to a level of over 33 thousand vehicles.

The sale of Toyota Prius in the United States started in 2000, however, after winning there the Car of the Year Award in 2004, the sale increased from 36 thousand (2003) up to 47 thousand vehicles, and waiting time for car amounted to 6 months.

In 2007 in the United States were sold more than 180 thousand Toyota Prius vehicles, while the next year the sale of this model achieved the level of 20 thousand cars per month. To the success of sales of Prius model on this largest (outside Japan) market contributed also a note from 2010 about Prius being the most economical car (the result: 50 miles $(80 \mathrm{~km})$ on one gallon of fuel $\left.\left(3.78 \mathrm{dm}^{3}\right)\right)$.

The first million of cars with the hybrid drive system Toyota sold after 9 years and 9 months since the beginning of the sale. Up to March 2014 (after 17 years of production), Toyota sold all over the world 6 million of such vehicles. Another million of vehicles with a hybrid drive system the company has sold in just six months, that is since September 2014 (Fig. 3).

The first Toyota Prius vehicle of the first generation was brought to Poland in 1999. This vehicle is currently used by the distributor of this company, i.e. Toyota Motor Poland with headquarters in Warsaw.

Currently in Poland five Toyota vehicles with hybrid drive system are available on the market (models: Yaris, Auris hatchback and estate, Prius of the 3rd generation sold since 2009 and Prius plug-in, as well as the biggest one - Prius + ).

In recent years in Poland there has been a significant increase in the sales of cars with hybrid drives. Data from the last 4 years is shown in Fig. 4.

Every fourth Toyota vehicle sold in Poland is the Auris model $(60 \%$ of sold vehicles are the hybrid vehicles of the estate type - Touring Sports).

The sale of the two most popular models of Toyota's hybrid drives in Poland in the years 2012-2014 is shown in Fig. 5.

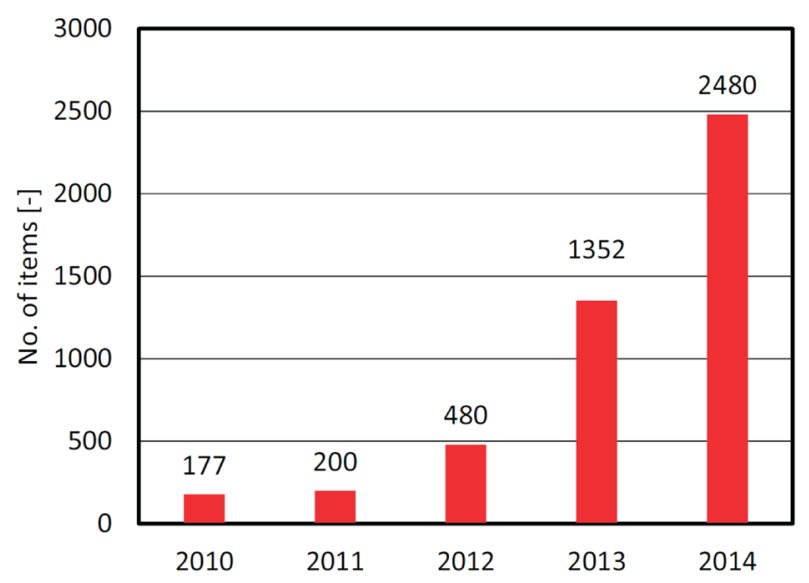

Fig. 4. The sale of Toyota hybrid vehicles in Poland in years 2010-2014 [12] Rys. 4. Sprzedaż pojazdów hybrydowych firmy Toyota $w$ Polsce w latach 2010-2014 [12]

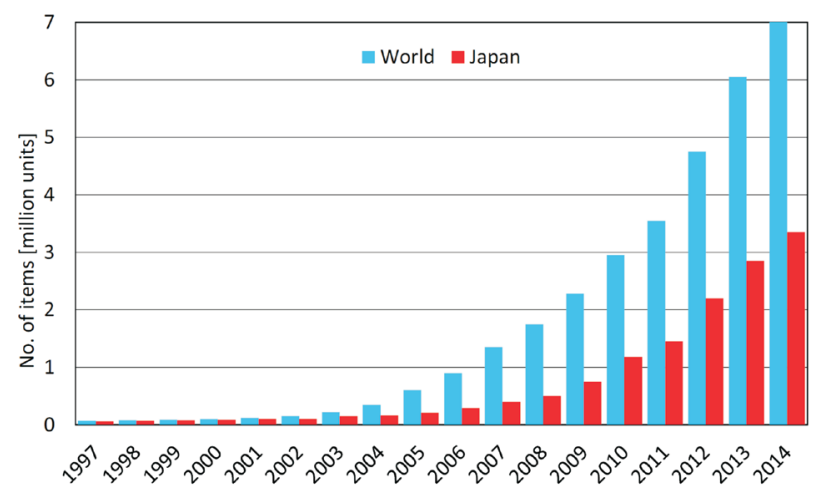

Fig. 3. The global sale of Toyota hybrid vehicles [15]

Rys. 3. Światowa sprzedaż samochodów hybrydowych firmy Toyota [15]

z 2010 roku o najbardziej ekonomicznym samochodzie (wynik 50 mil $(80 \mathrm{~km})$ na jednym galonie paliwa $\left.\left(3,78 \mathrm{dm}^{3}\right)\right)$.

Pierwszy milion samochodów z układami napędu hybrydowego firma Toyota sprzedała po 9 latach i 9 miesiącach od rozpoczęcia sprzedaży. Do marca 2014 roku (po 17 lat produkcji) firma Toyota sprzedała na całym świecie 6 milionów tych samochodów. Kolejny milion samochodów hybrydowych firma sprzedała w pół roku, czyli do września 2014 roku (rys. 3).

Pierwszy egzemplarz samochodu Toyota Prius 1. generacji sprowadzono do Polski w 1999 roku. Samochód ten obecnie jest eksploatowany przez dystrybutora tej firmy, tj. Toyotę Motor Poland z siedzibą w Warszawie. Obecnie w Polsce sprzedawanych jest pięć modeli pojazdów firmy Toyota $\mathrm{z}$ napędem hybrydowym (model Yaris, Auris z nadwoziem hatchback oraz kombi, Prius 3. generacji, sprzedawany od 2009 roku oraz Prius plug-in i największy $\mathrm{z}$ nich - Prius + ).

W ostatnich latach w Polsce nastąpił duży wzrost sprzedaży samochodów z napędem hybrydowym. Dane z ostatnich 4 lat przedstawiono na rys. 4 .

Co czwarty sprzedawany w Polsce model Toyoty to Auris (60\% sprzedaży pojazdów dotyczy modelu z napędem hybrydowym z nadwoziem kombi - Touring Sports). w Polsce

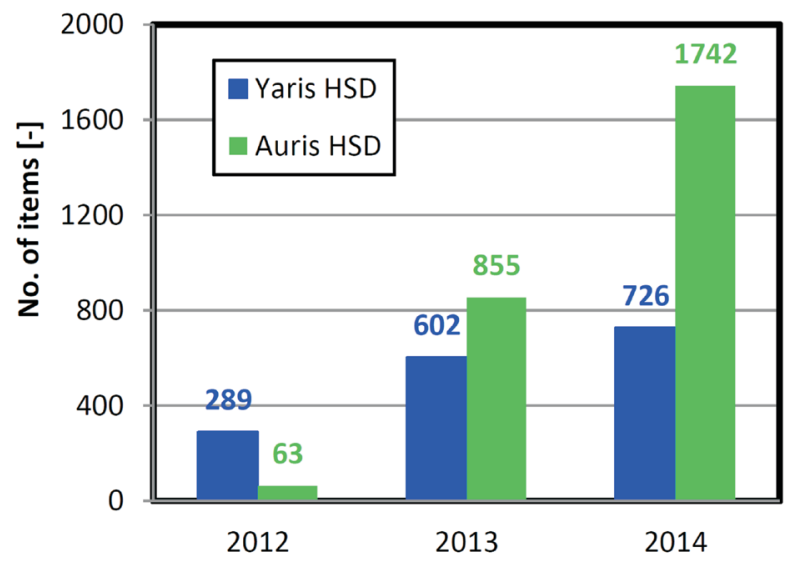

Fig. 5. The sale of popular models of Toyota hybrid drives in Poland [12] Rys. 5. Wielkość sprzedaży popularnych modeli firmy Toyota z napędem hybrydowym $w$ Polsce [12] 


\section{Research methodology}

Tests of hybrid vehicles in conditions of driving test were conducted with the use of three models of vehicles from Toyota (Table 1). These vehicles had the same solutions of the hybrid drive system, but different types and capacities of the high voltage electric batteries $[13,14]$. The research concerned the influence of the charge level of battery (SOC - state of charge) on the share of operation of the combustion engine and electrical motor in the UDC drive test.

The tests of hybrid vehicles it the UDC drive tests were carried out on the chassis dynamometer at the Motor Transport Institute in Warsaw: the bench tests were conducted on the chassis dynamometer of RPL1220/12 113/GPM 200 type by Zëllner with a roller of 48" diameter with electric simulation of the movement resistance and vehicle inertia (Fig. 6). The measurements, for the purpose of the com-
Wielkość sprzedaży dwóch najbardziej popularnych modeli Toyoty z napędem hybrydowym w Polsce w latach 2012-2014 przedstawiono na rys. 5 .

\section{Metodyka badań}

Badania pojazdów hybrydowych w warunkach testu jezdnego prowadzono z wykorzystaniem trzech modeli firmy Toyota (tabl. 1). Pojazdy te cechowały się jednakowymi rozwiązaniami układu napędu hybrydowego przy zróżnicowanych rodzajach i pojemnościach elektrycznych akumulatorów wysokonapięciowych $[13,14]$. Badania dotyczyły wpływu stopnia naładowania akumulatorów (SOC - state of charge) na udział pracy silnika spalinowego i elektrycznego w teście UDC.

$\mathrm{W}$ artykule przedstawiono badania pojazdów hybrydowych w testach jezdnych UDC przeprowadzonych na hamowni podwoziowej w Instytucie Transportu Samocho-

Table 1. Types and characteristics of batteries of the hybrid vehicles and the test conditions $[14,15]$

Tablica 1. Rodzaje i charakterystyka akumulatorów pojazdów hybrydowych oraz warunki prowadzenia badań [14, 15]

\begin{tabular}{|c|c|c|c|c|}
\hline Quantity/wielkość & & Toyota Prius plug-in & Toyota Prius + & $\begin{array}{c}\text { Toyota Auris Touring } \\
\text { Sport Hybrid }\end{array}$ \\
\hline Battery type/rodzaj akumulatorów & & Li-Ion & Li-Ion & $\mathrm{NiMH}$ \\
\hline No. of cell/liczba ogniw & szt. & $56(4 \times 14)$ & $56(2 \times 28)$ & $168(6 \times 28)$ \\
\hline Battery capacity/pojemność elektryczna akumulatorów & $\mathrm{A} \cdot \mathrm{h}$ & 21.5 & 5 & 6.5 \\
\hline Nominal voltage/napięcie znamionowe & $\mathrm{V}$ & 207.2 & $\leftarrow$ & 201.6 \\
\hline ICE displacement/objętość skokowa silnika spalinowego & $\mathrm{cm}^{3}$ & 1798 & $\leftarrow$ & $\leftarrow$ \\
\hline Maximum power output/maksymalna moc wyjściowa układu & $\mathrm{kW}$ & 100 & $\leftarrow$ & $\leftarrow$ \\
\hline Maximum speed/prędkość maksymalna & $\mathrm{kph}$ & 180 & 165 & 175 \\
\hline Acceleration $0-100 \mathrm{kph} /$ przyspieszenie $0-100 \mathrm{~km} / \mathrm{h}$ & $\mathrm{s}$ & 10.7 & 11.3 & 11.2 \\
\hline EV mode vehicle range/zasięg pojazdu w trybie EV & $\mathrm{km}$ & 24 & 2 & $\leftarrow$ \\
\hline \multicolumn{5}{|l|}{ Test conditions/warunki prowadzenia badań } \\
\hline $\mathrm{SOC} \min$ & $\%$ & 20 & 40 & 40 \\
\hline SOC max & $\%$ & 85 & 70 & 60 \\
\hline
\end{tabular}

parison, were performed during the UDC drive test, which reflects the urban traffic conditions. The main performance indexes of the drive system were measured with the use of the diagnostic tester: the combustion engine speed $-n$, electric motor speed - nMG2, generator speed - nMG1, charge level of the high voltage battery - SOC and vehicle speed - Vveh. Based on these parameters, the performance indexes for the drive system were calculated for the EV
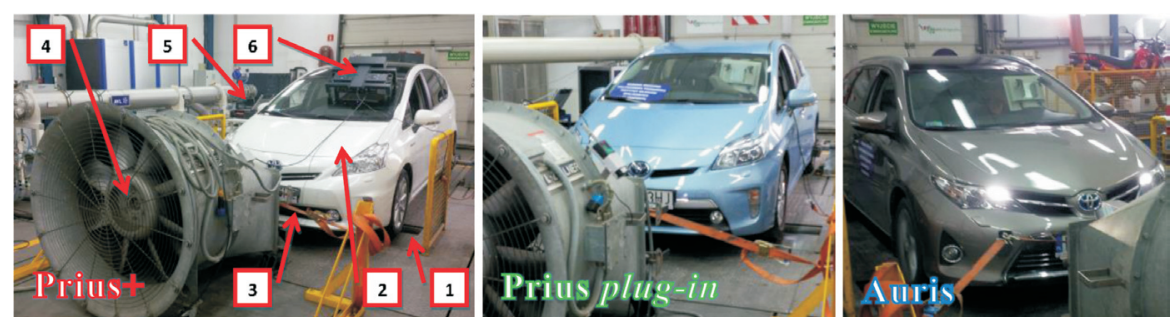

Fig. 6. Test stand: 1 - chassis dynamometer, 2 - tested vehicle, 3 - protection belts, 4 - fan, 5 - diagnostic computer, 6 - monitor showing the UDC drive test parameters

Rys. 6. Stanowisko badawcze: 1 - hamownia podwoziowa, 2 - pojazd badawczy, 3 - pasy zabezpieczajace, 4 -wentylator, 5 - komputer diagnostyczny, 6-monitor wyświetlajacy parametry testu UDC dowego w Warszawie. Badania stanowiskowe wykonano na hamowni podwoziowej firmy Zëllner typu RPL 1220/12 C 221 113/GPM 200 z rolką o średnicy 48" z elektryczną symulacją oporów ruchu i bezwładności pojazdu (rys. 6). Do celów porównawczych prowadzono badania w teście UDC, który odwzorowuje miejskie warunki ruchu pojazdu. Główne wskaźniki operacyjne układu napędu hybrydowego mierzono z użyciem testera diagnostycznego: prędkość obrotową silnika spalinowego - $\mathrm{n}$, prędkość obrotową silnika elektrycznego - nMG2, prędkość obrotową generatora - nMG1, stopień naładowania akumulatora wysokonapięciowego - SOC oraz prędkość pojazdu - Vveh. Na podstawie powyższych wielkości obliczono wskaźniki oceny pracy układu napędowego w trybie EV (elektrycznym) oraz w trybie HV (hybrydowym). Stopień naładowania akumulatora - SOC był wielkością bazową 

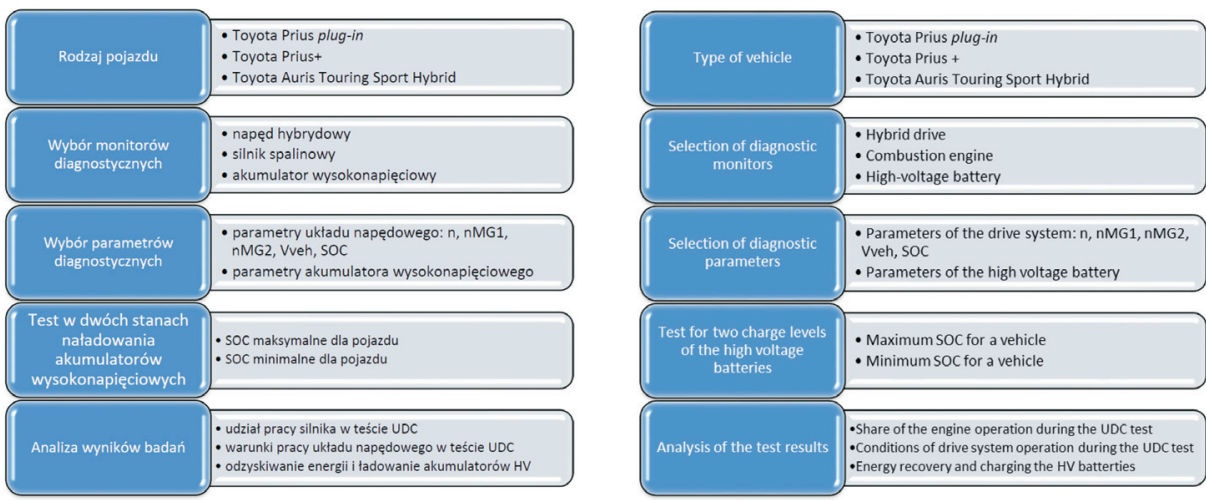

Fig. 7. Systematics of the conducted research on the hybrid drives

Rys. 7. Systematyka prowadzonych badań pojazdów hybrydowych w każdym teście, gdyż jednym z celów pracy było porównanie częstości uruchomień i czasu pracy silnika spalinowego od stanu naładowania akumulatora. Dla tak sformułowanego celu badawczego przeprowadzono po dwa testy każdego z trzech pojazdów. Pierwszy przejazd dotyczył ustalonego minimalnego poziomu SOC dla danego układu napędowego, a drugi - maksymalnego możliwego dla danego pojazdu stopnia naładowania akumulatorów.

Analizę warunków pracy mode (electric mode) and HV mode (hybrid mode). The charge level of the battery - SOC was the basis for each test, as one of the purposes of the work was to compare the dependency of the frequency of starts and time of operation of the combustion engines on the charge level of the battery. For so formulated research aim, two tests of each of the three vehicles were conducted. The first test run involved the determined minimum SOC level for a given drive system, and the other - the maximum possible charge level of battery for a given vehicle.

The analysis of the operation conditions was conducted in accordance with the diagram shown in Fig. 7.

\section{Characteristics of operation of the hybrid drive system in the UDC drive test}

\subsection{Influence of the charge level of battery on the number of engine starts}

The tests of the hybrid drives were carried out for the UDC drive test, during which the influence of the charge level of battery on the operational conditions of these drives was determined. In Figure 8 is shown a change of the SOC value in relation to the speed of the vehicle observed during the tests. Test UDC drive tests includes four elementary ECE R15 cycles, during which the vehicle is accelerated to the speed of $50 \mathrm{kph}[1,6]$. The average speed of the vehicle in the UDC drive test achieved Vav $=17.5 \mathrm{kph}$. Table 2 shows the difference between the registered initial and final values of SOC.

The hybrid drive of the tested vehicles allows operation of the combustion engines and electric motors in several modes: EV (electric propulsion) - propulsion only using electricity accumulated in the high voltage battery and HV (hybrid propulsion) - propulsion utilising the combustion engine and electric motor. A characteristic feature in this division is the number of starts of the combustion engine during the UDC drive test. Figure 9 shows the number of starts of combustion engine taking into account the initial charge level of the battery.

Analysis of Fig. 9 shows that number of starts of the combustion engine in the UDC drive test is the same for all tested vehicles (apart from Prius plug-in model), but the conditions of starting and the operation time are different. For układów napędowych prowadzono zgodnie ze schematem przedstawionym na rys. 7 .

\section{Charakterystyka pracy układu napędu hybrydowego w teście UDC}

\subsection{Wpływ stopnia naładowania akumulatora na licz- bę uruchomień silnika}

Badania pojazdów hybrydowych wykonano w teście UDC, podczas którego określono wpływ stopnia naładowania akumulatorów na warunki pracy napędów. Na rysunku 8 , na tle zadanej prędkości pojazdu, przedstawiono zmianę wartości SOC podczas trwania testów. Test UDC składa się z czterech elementarnych cykli ECE R15, podczas których pojazd rozpędzany jest do prędkości $50 \mathrm{~km} / \mathrm{h}[1,6]$. Średnia prędkość pojazdu w teście UDC wynosiła Vśr $=17,5 \mathrm{~km} / \mathrm{h}$. $\mathrm{W}$ tablicy 2 przedstawiono różnicę między zarejestrowanymi początkowymi i końcowymi wartościami SOC.

Układy napędu hybrydowego badanych pojazdów umożliwiają pracę w kilku trybach wykorzystania silników spalinowego i elektrycznego: EV (electric propulsion) napęd wyłącznie z wykorzystaniem energii elektrycznej zgromadzonej w akumulatorze wysokonapięciowym oraz HV (hybrid propulsion) - napęd wykorzystujący silnik spalinowy i silnik elektryczny. Charakterystycznym elementem tego podziału jest liczba uruchomień silnika spalinowego podczas testu UDC. Na rysunku 9 przedstawiono liczbę uruchomień silnika spalinowego uwzględniającą początkową wartość naładowania akumulatora.

Analiza rysunku 9 wskazuje na jednakową liczbę uruchomień silnika spalinowego w teście UDC (poza pojazdem Prius plug-in), jednak warunki uruchomienia silnika i czas pracy są odmienne. Dla małych wartości SOC silnik spalinowy uruchamiany był już podczas minimalnego lub częściowego przyspieszania, natomiast dla dużego SOC - podczas zwiększonego obciążenia wynikającego z warunków testu. Przykładowe warunki, których spełnienie umożliwia uruchomienie trybu elektrycznego zestawiono w tablicy 3.

\subsection{Warunki pracy układu napędowego}

Liczba uruchomień silnika spalinowego umożliwiła wyznaczenie czasu jego pracy w teście UDC (rys. 10), 
Table 2. Changes in the charge level of batteries of the tested vehicles in the UDC drive test

Tablica 2. Zmiany stopnia naładowania akumulatorów $w$ badanych pojazdach podczas testu UDC

\begin{tabular}{|l|c|c|c|}
\hline Vehicle/pojazd & SOCstart & SOCend & $\Delta$ SOC \\
\hline \multirow{2}{*}{ Prius plug-in } & 19.2 & 19.2 & 0 \\
\cline { 2 - 4 } & 85.4 & 74.1 & -11.3 \\
\hline \multirow{2}{*}{ Prius+ } & 39.6 & 49.4 & +9.8 \\
\cline { 2 - 4 } & 70.1 & 50.9 & -19.2 \\
\hline \multirow{2}{*}{ Auris } & 41.9 & 48.2 & +6.3 \\
\cline { 2 - 4 } & 60.7 & 47.8 & -12.9 \\
\hline
\end{tabular}

small values of SOC the combustion engine was started even for minimal or partial acceleration, while for larger values of SOC - during an increased load ensuing from the test conditions. Examples of driving conditions for which activation of the electric mode is possible are shown in Table 3.

\subsection{Operating conditions of the drive system}

The number of starts of combustion engine enables determining its operation time during the UDC drive test (Fig. $10)$, with the division into the elementary parts. The operation time share of the combustion engine is highest in tests with the minimum charge level of the battery. It is also the highest for the first cycle of the UDC drive test in which the combustion engine operates longer because of the warm-up phase and its function as a generator.

The operation of the combustion engine in conditions of varying speeds and loads in the function of the charge level of the batteries is shown in Fig. 11. The analysed characteristics do not indicate the existence of the dependency between the manner of combustion engine operation and the charge z podziałem na elementarne fragmenty. Czas pracy silnika spalinowego jest największy w testach przy minimalnym stopniu naładowania akumulatorów. Jest on również największy dla pierwszego cyklu UDC, w którym silnik spalinowy pracował dłużej (niż w innych fragmentach tego testu) ze względu na fazę jego rozgrzewania oraz pełniąc funkcję generatora.

Pracę silnika spalinowego w zmiennych warunkach prędkości i obciążenia w zależności od stopnia naładowania akumulatorów przedstawiono na rys. 11. Analizowane charakterystyki nie wskazują na istnienie zależności między warunkami pracy silnika spalinowego a wielkością naładowania akumulatorów. Analiza pracy tych jednostek napędowych wskazuje równocześnie na uzyskiwanie niewielkich prędkości obrotowych silników spalinowych przy

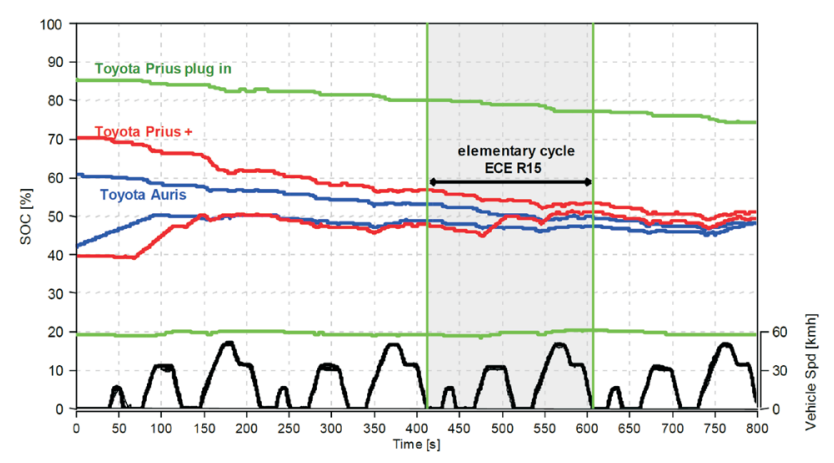

Fig. 8. The analysis of the charge level of batteries of hybrid vehicles in the UDC drive test

Rys. 8. Analiza stopnia naładowania akumulatorów pojazdów hybrydowych $w$ teście jezdnym UDC
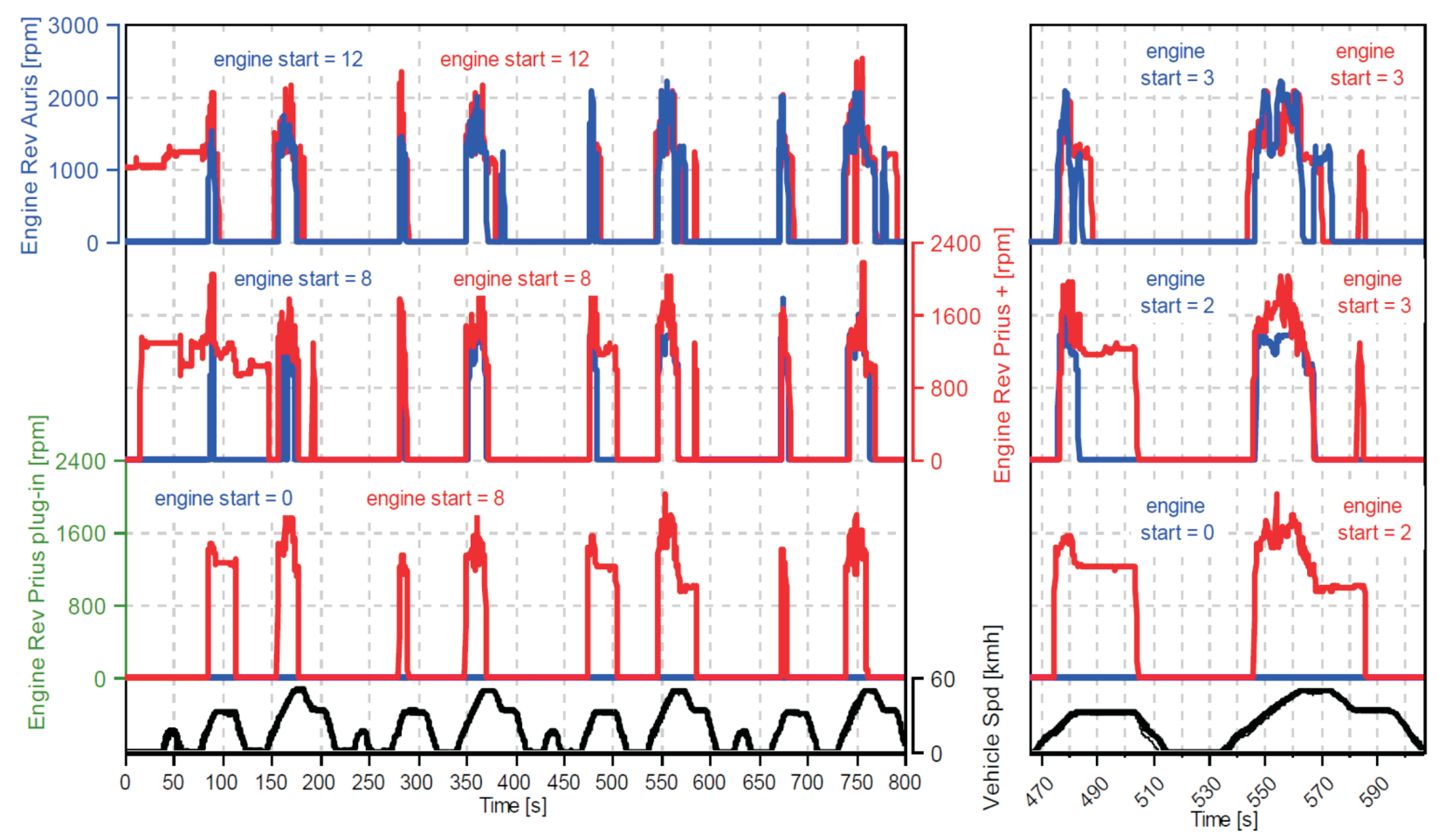

Fig. 9. An analysis of the number of combustion engine starts (red - SOCmin, blue - SOCmax) Rys. 9. Analiza liczby uruchomień silnika spalinowego (kolor czerwony-SOCmin, niebieski-SOCmax) 
Table 3. Selected conditions required to activate EV mode in a vehicle [15]

Tablica 3. Wybrane warunki wymagane do uruchomienia pojazdu w trybie EV [15]

\begin{tabular}{|c|c|}
\hline Vehicle/pojazd & Activation conditions/warunki działania \\
\hline Auris/Prius+ & $\begin{array}{l}\text { - temperature of the engine coolant is approx. } 0^{\circ} \mathrm{C} \text { or higher/temperatura plynu chtodzacego silnika wynosi ok. } 0^{\circ} \mathrm{C} \text { lub } \\
\text { więcej, } \\
\text { - the battery charge level (SOC) is at least } 50 \% / \text { wartość stanu naładowania SOC wynosi co najmniej } 50 \%, \\
\text { - the vehicle speed is approx. } 30 \mathrm{kph} \text { or lower (when the engine is cold)/prędkość pojazdu-ok. } 30 \mathrm{~km} / \mathrm{h} \text { lub mniej (przy } \\
\text { zimnym silniku), } \\
\text { - the vehicle speed is approx. } 45 \mathrm{kph} \text { or lower (when the engine is warm) } / \text { prędkość pojazdu - ok. } 45 \mathrm{~km} / \mathrm{h} \text { lub mniej (przy } \\
\text { rozgrzanym silniku), } \\
\text { - rear window heating is turned off/ogrzewanie tylnej szyby jest wyłaczone, } \\
\text { - the system maintaining constant driving speed is turned off/układ utrzymywania stałej prędkości jazdy jest wytaczony }\end{array}$ \\
\hline Prius plug-in & $\begin{array}{l}\text { - the vehicle speed is approx. } 100 \mathrm{kph} \text { or lower/prędkość pojazdu wynosi ok. } 100 \mathrm{~km} / \mathrm{h} \text { lub mniej, } \\
\text { - the position of the accelerator pedal is within the range/położenie pedału przyspieszenia jest w zakresie: } \\
\text { a) below } 40 \% \text { for higher speeds/poniżej } 40 \% \text { dla dużych prędkości, } \\
\text { b) below } 80 \% \text { for lower speeds/poniżej } 80 \% \text { dla małych prędkości, } \\
\text { - no air conditioning activated/brak wymuszenia działania uktadu klimatyzacji }\end{array}$ \\
\hline
\end{tabular}

level of the battery. The analysis of operation of those drive systems indicates simultaneously obtaining insignificant combustion engine speeds at quite significant loads. It means that these systems use the operational ranges of the engine with high general efficiency. Quite characteristic is formation of the conditions of engine operation for higher engine speeds (above idling) in conditions of minimum loads, and much higher loads for speeds of 1000-1500 rpm. Similar characteristics were obtained by the authors during tests of another of the hybrid drive system [11].

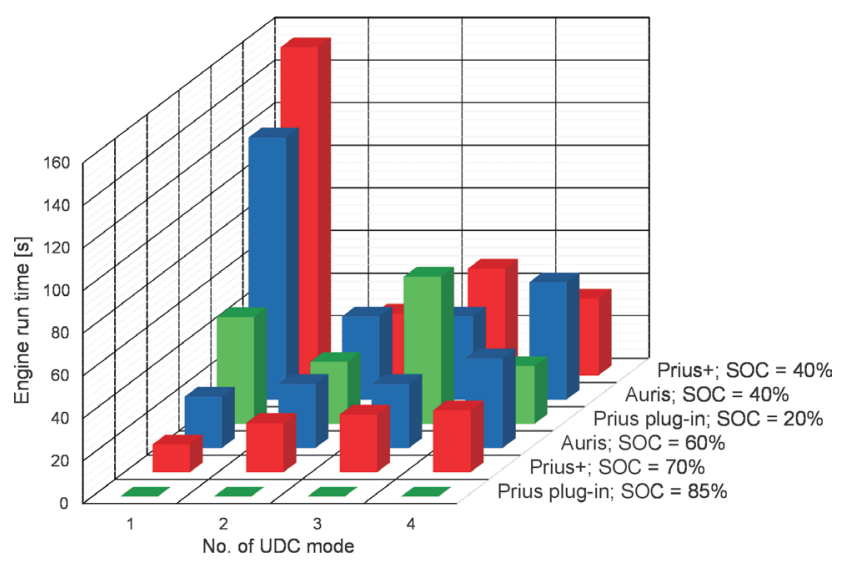

Fig. 10. The operation time share of the combustion engine in particular phases of the UDC test depending on the charge level of the batteries

Rys. 10. Czas pracy silnika spalinowego w poszczególnych fazach testu UDC $w$ zależności od stopnia naładowania akumulatorów

The above-mentioned analysis does not allow obtaining a full characterization of performance parameters of combustion engines; therefore the frequency of their operation was determined for ranges of the engine speeds (Fig. 12). The analysis of this figure indicates the existence of significant share (sampling was carried out at regular intervals) of engine operation time for speeds from within the range of 1200-1600 rpm. Regardless of the charge level of the battery, the share of operation time of the combustion engine in the mentioned range of engine speeds was the highest. dość znacznym ich obciążeniu. Oznacza to, że jednostki te wykorzystują obszary pracy o dużej sprawności ogólnej silnika. Charakterystyczne jest kształtowanie warunków pracy silnika podczas podwyższonej prędkości obrotowej (powyżej biegu jałowego) w warunkach minimalnego obciążenia oraz znaczne zwiększenie obciążenia przy prędkości 1000-1500 obr/min. Podobne charakterystyki uzyskano podczas badań innego układu napędu hybrydowego [11].

Powyższe analizy nie dały pełnej charakterystyki warunków pracy silników spalinowych i dlatego wyznaczono częstości ich pracy w przedziałach prędkości obrotowych - rys. 12. Analiza tego rysunku wskazuje na istnienie znacznego udziału czasu pracy (próbkowanie odbywało się w stałych przedziałach czasu) silnika przy prędkości obrotowej w zakresie 1200-1600 obr/min. Niezależnie od stopnia naładowania akumulatorów udział czasu pracy silnika spalinowego we wspomnianym przedziale prędkości obrotowych jest największy.

Czas pracy silnika spalinowego posłużył do wyznaczenia drogi przebytej przez pojazd w trybie hybrydowym oraz elektrycznym (tryb ten rozpoznawano przez analizę zerowej prędkości obrotowej silnika spalinowego). Na rysunku 13 przedstawiono skumulowane wartości drogi przebytej przez pojazdy w takich trybach jazdy. Większy początkowy stopień naładowania akumulatorów umożliwia uzyskanie większego zasięgu pojazdów w trybie elektrycznym. Z przeprowadzonych badań wynika, że zasięg pojazdu w trybie elektrycznym zależy nie tylko od stopnia naładowania akumulatorów, ale również od ich pojemności. Dla pojazdów Toyota Auris, Prius + oraz Prius plug-in uzyskano podobne zasięgi w trybie elektrycznym przy zróżnicowanych wartościach SOC. Pojazd Toyota Prius plug-in ma zastosowane akumulatory o większej pojemności elektrycznej (Li-Ion), dzięki czemu przy mniejszej wartości początkowego SOC, w porównaniu do pozostałych badanych pojazdów, zasięg w trybie EV jest jednakowy. Jednakże ogólna tendencja wskazuje na zwiększenie zasięgu w trybie elektrycznym wraz ze zwiększeniem stopnia naładowania akumulatorów. Po przekroczeniu wartości $\mathrm{SOC}=70 \%$ udział pracy silnika spalinowego w napędzie pojazdu jest minimalny. Dla pojazdu o wartości naładowania akumulatorów $\mathrm{SOC}=85 \%$ (pełne naładowanie 


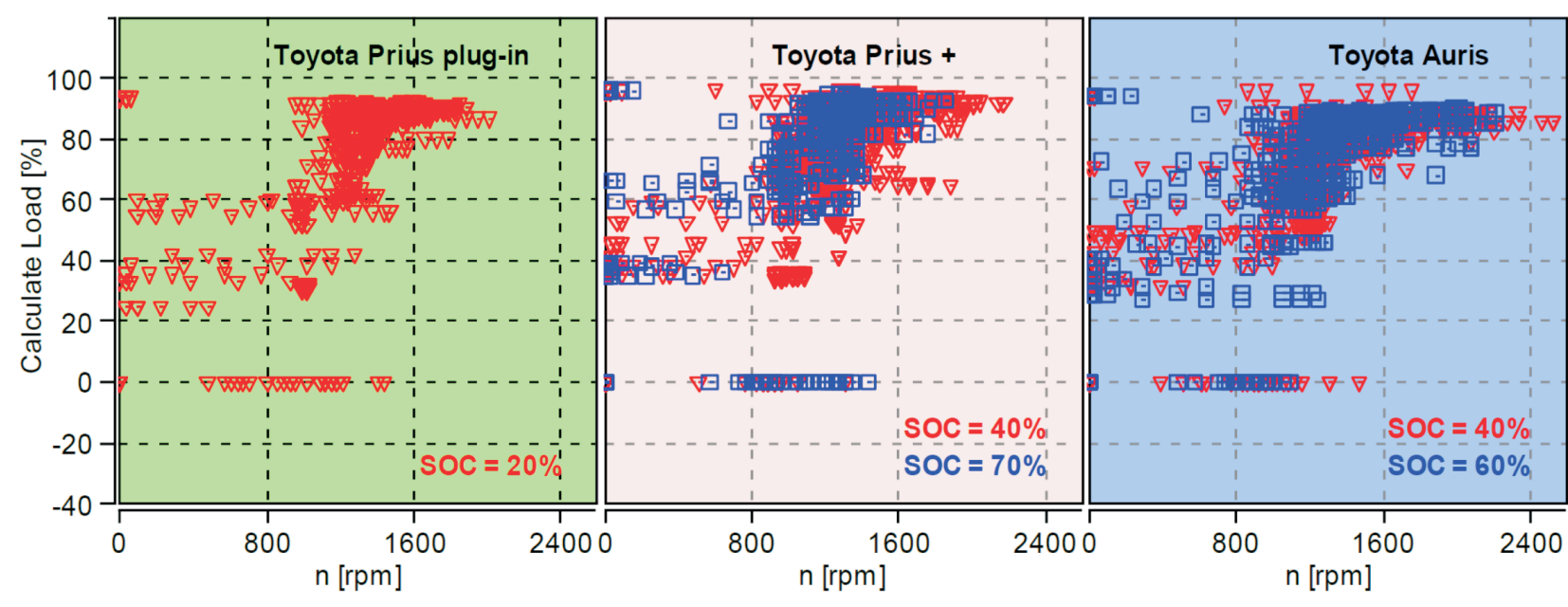

Fig. 11. The operational range of the combustion engine for different initial charge levels of accumulators (frequency of sampling - below $500 \mathrm{~ms}$ ) Rys. 11. Obszary pracy silnika spalinowego przy zróżnicowanych poziomach początkowego stopnia naładowania akumulatorów (częstotliwość próbkowania poniżej $500 \mathrm{~ms}$ )

The share of combustion engine operation time was used to determine the distance travelled by the vehicle in hybrid and electric mode (this mode was recognised on the basis of zero speed of the combustion engine). Figure 13 shows the cumulative distance travelled by vehicles in such driving modes. Higher initial charge level of batteries enabled obtaining further distances of the vehicle in the electric mode. The test results indicate that the distance travelled by the vehicle in the electric mode depends not only on the charge level of batteries but also on their capacity. For Toyota Auris, Prius+ and Prius plug-in vehicles were obtained similar distances in the electric mode for different values of SOC. Toyota Prius plug-in uses battery with higher electric capacity (Li-Ion) due to which at lower value of initial SOC, compared to the remaining vehicles, the distances travelled in EV mode were identical. However, the overall trend indicates an increase of the distances travelled in the electric mode with the increasing charge level of the battery. After obtaining z gniazda sieciowego) nie występuje uruchomienie silnika spalinowego w teście jezdnym UDC. Oznacza to, że duże wartości naładowania akumulatorów mogą zapewnić duży zasięg pojazdu w trybie elektrycznym, szczególnie podczas jazdy miejskiej.

Na rysunku 14 przedstawiono procentowy udział wybranego układu napędowego w czasie testu. $Z$ analizy tego rysunku wynika, że udział pracy pojazdu z wykorzystaniem tylko napędu elektrycznego wynosi ponad $50 \%$ całego testu UDC. Wartości takie otrzymano przy minimalnym poziomie naładowania akumulatorów. Zwiększenie stopnia naładowania akumulatorów powoduje, że udział ten wynosi ponad $65 \%$. Dla pojazdu Toyota Prius plug-in, dla którego poziom naładowania akumulatorów wynosił $85 \%$, przejazd całego testu UDC odbywał się w trybie elektrycznym.

Podczas poruszania się pojazdu w trybie elektrycznym (EV) napęd na koła realizowany jest tylko przez silnik elektryczny (MG2). Na rysunku 15 przedstawiono obszary
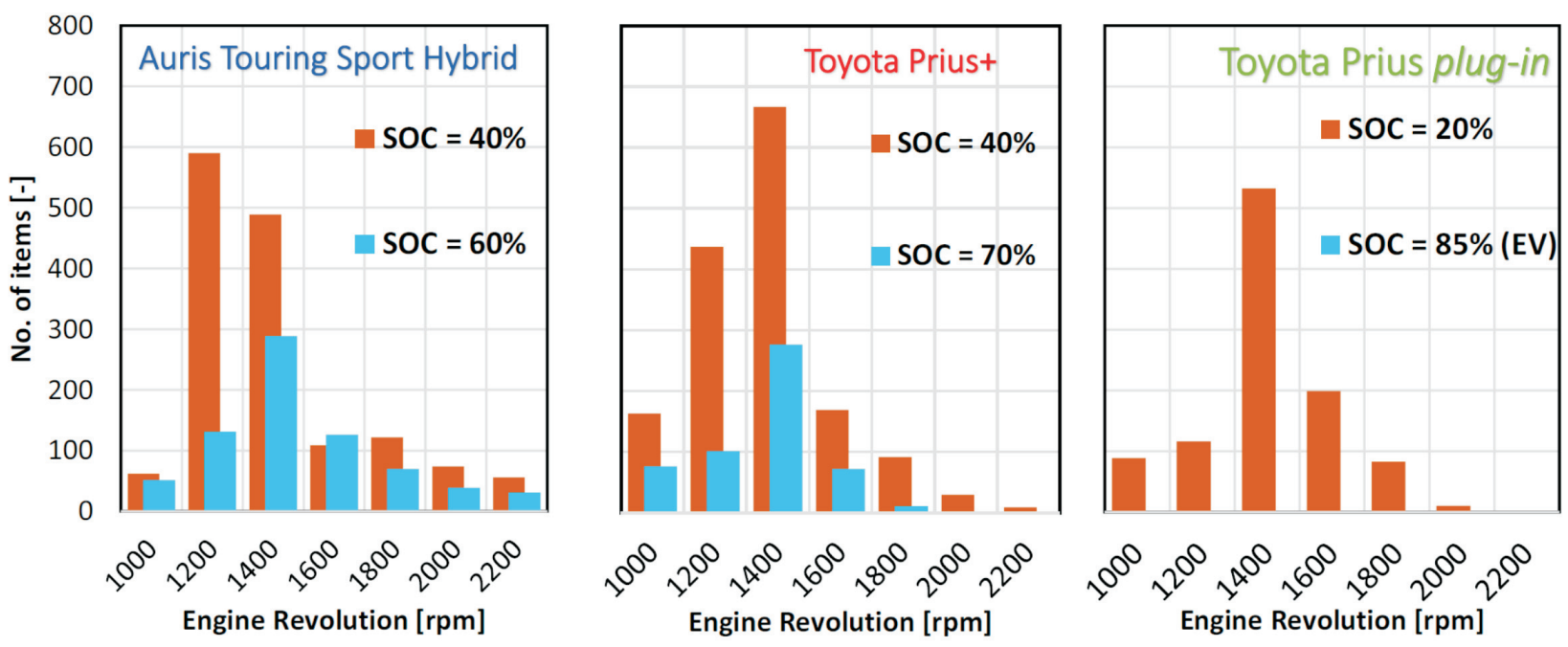

Fig. 12. The interval analysis of combustion engine speeds within particular ranges in the UDC drive test Rys. 12. Analiza przedziałowa prędkości obrotowej silnika spalinowego w teście UDC 
the $\mathrm{SOC}$ value $=70 \%$ the share of the combustion engine in the vehicle propulsion is minimal. For a vehicle with charge level of batteries $\mathrm{SOC}=85 \%$ (fully charged from the mains socket) the combustion engine in the UDC drive test is not activated at all. It means that large values of charge level of battery (SOC) can provide significant range of operation of a vehicle in the electric mode, especially when driving in urban conditions.

Figure 14 shows the percentage share of the selected propulsion modes during the test. From the analysis of this figure ensues that the share of vehicle operation using only electric motor amounts to more than $50 \%$ of the whole time of the UDC drive test. Such values were obtained only for minimum charge level of batteries. An increase in the charge level of the batteries caused an increase in this share to more than $65 \%$. For Toyota Prius plug-in vehicle, for which the charge level of battery was $85 \%$, the whole UDC test run was in electric mode.

During the vehicle operation in the electric mode (EV) the wheels are propelled only by the electric motor (MG2). Figure 15 shows operation areas of this engine in the UDC drive test. From the operation conditions of the vehicle (the same drive test) ensue characteristic operation ranges of the engine MG2. A slightly larger load of the electric motor mounted in the Toyota Auris vehicle should be noted, particularly for low speeds of this engine. Electric propulsion of Toyota Prius + uses lower values of the torque at high engine speeds; however, the conditions of energy recovery are similar for all tested vehicles (negative torque values are shown in Fig. 15).

The analysis of the share of combustion engine operation time in the UDC drive test enables estimating not only the time of its operation (Fig. 16a), but also allows detailed analysis of operating conditions. The figure shows the conditions of combustion engine and electric motor operation at the minimum charge level of the battery. The results of the analysis indicate the minimum share of idling (it applies to each vehicle). A significant share of operation time of the combustion engine in the time of the entire drive test (the shares at levels of 0.05) applies to large loads at average engine speeds. These are ranges of high efficiency of the combustion engine. Additionally, the results of the analysis are shown as the function of the relative load, which does
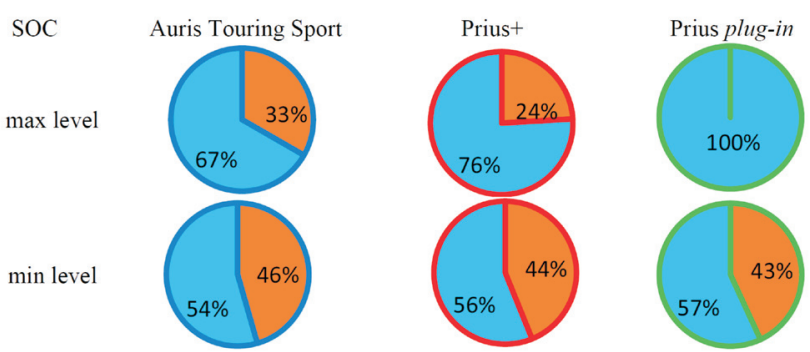

Fig. 14. The percentage share of the distance travelled with the use of electric propulsion (EV - blue) and hybrid propulsion ( $\mathrm{HV}$ - orange) in the UDC drive test

Rys. 14. Udziat procentowy przebytej drogi z wykorzystaniem układu napędu elektrycznego (EV-niebieski) oraz hybrydowego (HV-pomarańczowy) w teście UDC

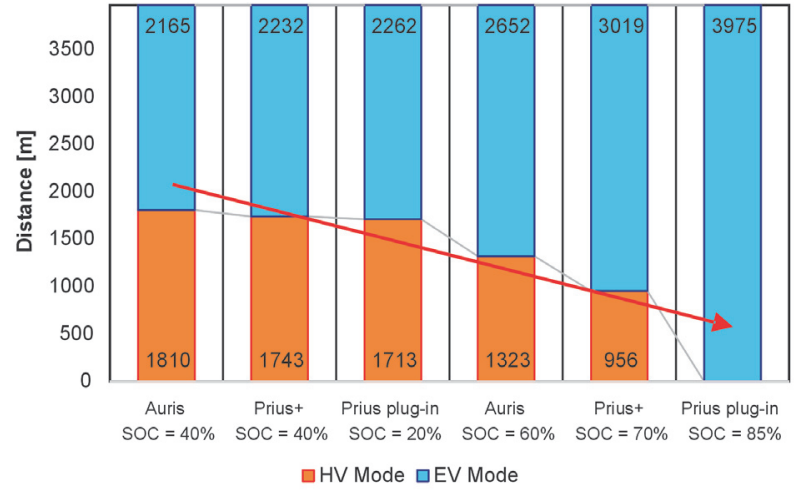

Fig. 13. Accumulated distances travelled by a vehicle in EV and HV modes depending on the initial charge level of accumulators in the UDC drive test

Rys. 13. Skumulowany zasięg pojazdu w trybie EV i HV w zależności od początkowego stopnia naładowania akumulatorów $w$ teście UDC

pracy tego silnika w teście UDC. Z warunków pracy pojazdu (ten sam test jezdny) wynikają charakterystyczne obszary pracy silnika MG2. Należy zauważyć nieco większe obciążenia silnika elektrycznego zamontowanego w pojeździe Toyota Auris, szczególnie przy jego małych prędkościach obrotowych. Układ napędu elektrycznego Toyoty Prius + wykorzystuje mniejsze wartości momentu obrotowego przy dużych prędkościach obrotowych, jednak warunki odzyskiwania energii są zbliżone dla wszystkich badanych pojazdów (ujemne wartości momentu obrotowego widoczne na rys. 15).

Analiza pracy silnika spalinowego w teście UDC pozwala na oszacowanie nie tylko czasu jego pracy (rys. 16a), ale również umożliwia szczegółową ocenę warunków pracy. $\mathrm{Na}$ rysunku tym przedstawiono warunki pracy silników spalinowego i elektrycznego przy minimalnym stopniu naładowania akumulatorów. Wyniki analiz wskazują na minimalny udział biegu jałowego (dotyczy to każdego z pojazdów). Znaczny czas pracy silnika spalinowego w całym teście ( $\mathrm{z}$ udziałami na poziomie 0,05 ) dotyczy dużych obciążeń w zakresie średnich prędkości obrotowych. Są to obszary dużej sprawności silnika spalinowego. Wyniki tych analiz dodatkowo przedstawiono w odniesieniu do względnego obciążenia, co nie wskazuje jednoznacznie na wartości momentu obrotowego (jest to obciążenie względne przy danej prędkości obrotowej). Z tego powodu przy mniejszych prędkościach obrotowych wyznaczone są znaczne obciążenia.

$\mathrm{Na}$ podstawie przeprowadzonych badań stwierdzono, że mały stopień naładowania akumulatorów zwiększa czas pracy silnika spalinowego w teście UDC. Początkowe zwiększenie stopnia naładowania akumulatora o $10 \%$ zmniejsza czas pracy silnika spalinowego o około $60 \mathrm{~s}$ (dla Toyoty Prius+ oraz Toyoty Auris) oraz o około 30 s dla Toyoty Prius plug-in (wynika to z większej pojemności elektrycznej akumulatorów).

Warunki pracy silnika elektrycznego (rys. 16b) dotyczą obszarów zróżnicowanych pod względem sprawności. Jednak duży udział pracy tego silnika w całym zakresie testu UDC przypada przy dużych wartościach sprawności (obszar 


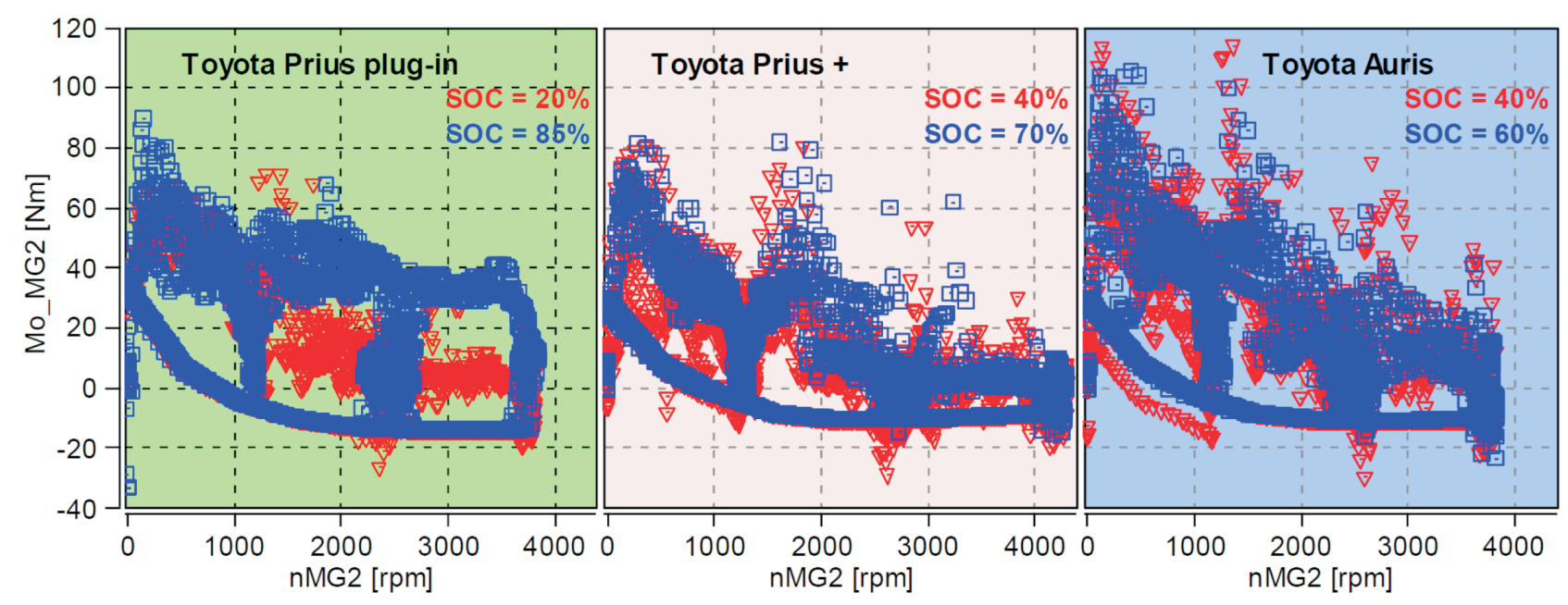

Fig. 15. Ranges of operation of electric motor MG2

Rys. 15. Obszary pracy silnika elektrycznego MG2

not clearly indicate the torque values (this is the relative load at a given engine speed). For this reason, at lower engine speeds occur significant loads.

On the basis of tests conducted, it was concluded that low charge level of the battery increases the combustion engine operation time in the UDC drive test. The initial increase of the charge level of battery by $10 \%$ reduces the combustion engine operation time to approximately $60 \mathrm{~s}$ (for Toyota Prius + and Toyota Auris) and to approximately 30 $\mathrm{s}$ for Toyota Prius plug-in (which is associated with higher electric capacity of the battery).

Conditions of operation of electric motor (Fig. 16b) apply to ranges differing in terms of efficiency. However, significant share of this engine operation in the whole range of the UDC test falls within high values of efficiency (range from 1600 to $3200 \mathrm{rpm}$ and partial load). In all conducted tests a significant share of electric motor operation time was found for speed of $2400 \mathrm{rpm}$ (or slightly higher depending on the main gear ratio of the vehicle) and significant load (share over $8 \%$ ). These points correspond to the constant speeds of vehicle of approximately $50 \mathrm{kph}$ resulting from the test phase.

\subsection{Conditions for energy recovery and battery charging in the UDC drive test}

Charging battery while driving a vehicle increases its travelling distance, however it causes also an increase of the share of operation time of combustion engine in the entire UDC drive test. Figure 17 shows the values of battery charging energy resulting from the generator operation and vehicle braking. For lower initial charge level of batteries, their charging starts even during the first part of the UDC drive test. High level of initial charge of batteries results in insignificant changes in their charging during the entire UDC drive test. The minimal initial charge level of batteries of Toyota Auris vehicle during the UDC test changed from the value of $41.9 \%$ to $48.2 \%$ (difference of $6.3 \%$ ). For Toyota Prius + vehicle those values amounted to, respectively, $39.6 \%$ and $49.4 \%$ (difference of $9.8 \%$ ). Only for the Toyota w zakresie 1600-3200 obr/min oraz częściowym obciążeniu). We wszystkich prowadzonych badaniach stwierdzono duży udział czasu pracy silnika elektrycznego przy prędkości 2400 obr/min (lub nieco większej w zależności od przełożenia przekładni głównej pojazdu) i znacznym obciążeniu (udział powyżej 8\%). Punkty te odpowiadają stałym prędkościom pojazdu około $50 \mathrm{~km} / \mathrm{h}$ wynikającym z faz testu.

\subsection{Warunki odzyskiwania energii i ladowania aku- mulatorów pojazdów w teście UDC}

Ładowanie akumulatorów w czasie jazdy pojazdu zwiększa jego zasięg, jednak powoduje zwiększenie udziału czasu pracy silnika spalinowego w całym teście UDC. Na rysunku 17 przedstawiono wartości energii ładowania akumulatorów wynikające z pracy generatora oraz $\mathrm{z}$ hamowania pojazdem. Przy mniejszym początkowym stopniu naładowania akumulatorów ich ładowanie rozpoczyna się już w pierwszym fragmencie testu UDC. Duży stopień początkowego naładowania akumulatorów skutkuje niewielkimi zmianami w ich ładowaniu podczas całego testu UDC. Minimalny początkowy stopień naładowania akumulatorów pojazdu Toyota Auris podczas testu UDC zmienił się z wartości 41,9\% do 48,2\% (zmiana o 6,3\%). Dla pojazdu Toyoty Prius+ wartości te wyniosły odpowiednio: 39,6\% oraz 49,4\% (zmiana o 9,8\%). Jedynie dla pojazdu Toyoty Prius plug-in przy początkowym naładowaniu akumulatorów o wartości 19,2\% nie nastąpiła jego zmiana po ukończeniu testu. Wynika to ze strategii pracy układu napędu hybrydowego wyposażonego w złącze umożliwiające doładowanie z sieci elektrycznej, gdy akumulatory są doładowane i rozładowane w zakresie niewielkich zmian SOC. Występuje tu tzw. doładowanie podtrzymujące, które nie prowadzi do znacznych (dodatnich) zmian stopnia naładowania akumulatorów. Jest to cecha pojazdów hybrydowych określanych mianem plug-in.

Na rysunku 17 przedstawiono wartości energii zgromadzonej w akumulatorach wynikające z dwóch warunków: doładowania akumulatorów w wyniku pracy silnika spalinowego i generatora oraz w wyniku hamowania regeneracyjnego. Energię hamowania określono w warunkach ujemnego 
a) combustion engine/silnik spalinowy
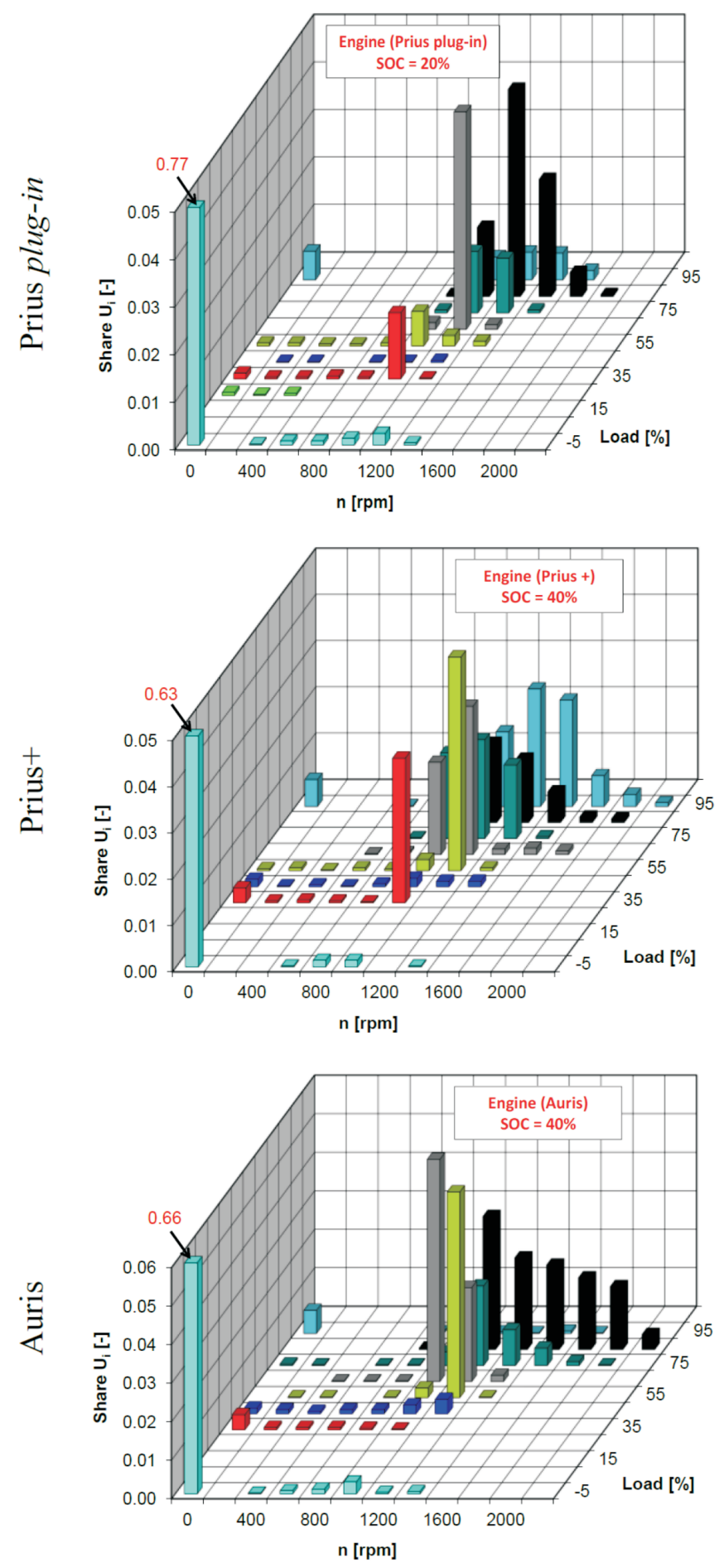

b) motor/silnik elektryczny
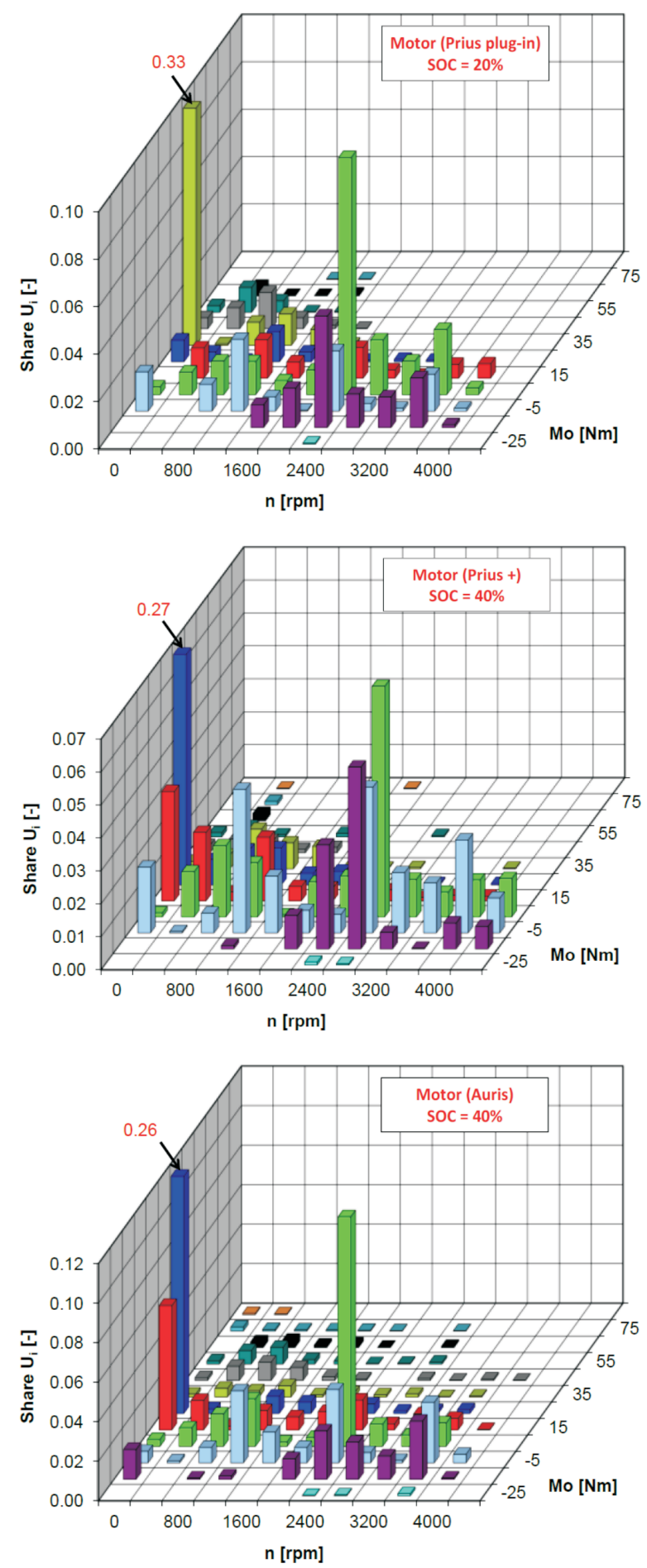

Fig. 16. The characteristics of time density of operation of the combustion engine (a) and electric motor (b) of the vehicles with hybrid drive system Rys. 16. Charakterystyki gęstości czasowej pracy silnika spalinowego (a) i silnika elektrycznego (b) badanych pojazdów z układem napędu hybrydowego

Prius plug-in vehicle with the initial charge level of battery of $19.2 \%$ there was no change in this parameter on completion of the test. This is due to the strategy of operation of the hybrid drive system equipped with a socket enabling charging from the mains when the battery is recharged and przyspieszenia pojazdu (hamowania) oraz wyłączonego silnika spalinowego.

Zestawienie wartości energii ładowania dla badanych pojazdów wskazuje na istnienie związku ze stopniem naładowania akumulatorów (rys. 18). Energia ładowania aku- 
discharged within the range of insignificant changes of SOC. There occurs so-called charge sustaining which does not lead to substantial (positive) changes of the charge level of batteries. This is a unique feature of the hybrid vehicles called plug-in.

Figure 17 shows the values of energy accumulated in batteries depending on two conditions: recharging batteries through operation of the combustion engine and the generator operation caused by energy recovering braking of the vehicle. The braking energy was determined in conditions of vehicle deceleration (braking) and for deactivated combustion engine.

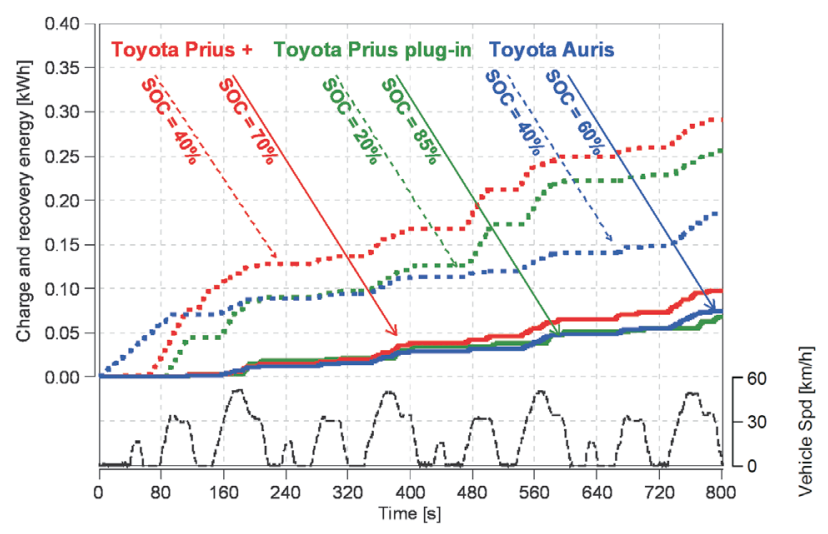

Fig. 17. Conditions of recharging high-voltage accumulator with the use of combustion engine and the vehicle's kinetic energy

Rys. 17. Warunki ładowania akumulatorów wysokonapięciowych przy wykorzystaniu silnika spalinowego oraz energii kinetycznej pojazdu

The summary of the recharging energy for the tested vehicles shows the existence of a relation with the charge level of battery (Fig. 18). The recharging energy of the batteries in the UDC drive test is higher when the initial charge level of batteries is lower. This trend, however, although predictable, takes into account also the electric capacity of the batteries (ability of storing energy). The analysis of the battery recharging energy presented in Fig. 18 indicates that increasing this energy does not always lead to the increase of SOC.

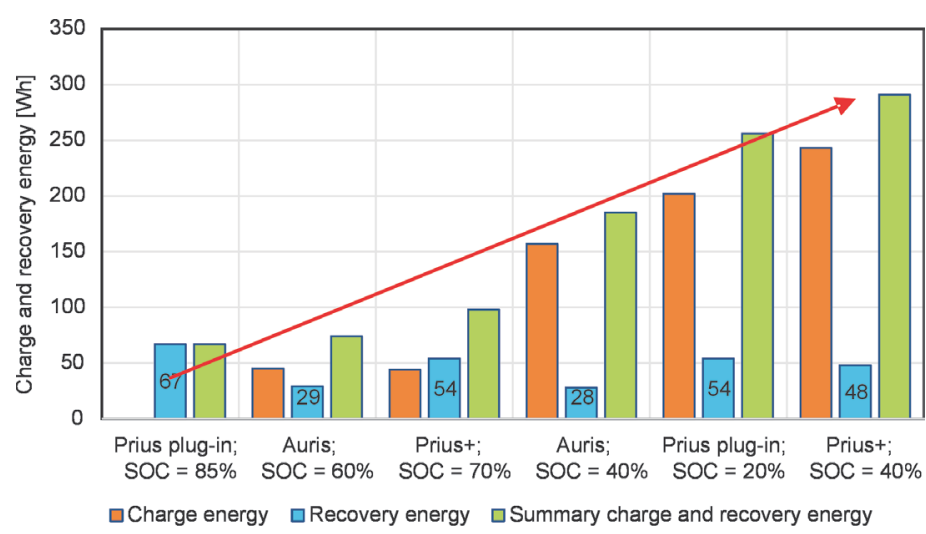

Fig. 18. The values of energy recovered from vehicle braking and recharging with the use of combustion engine

Rys. 18. Wartości energii odzyskanej z hamowania pojazdu oraz z ładowania silnikiem spalinowym mulatorów w teście UDC jest większa, gdy początkowe ich naładowanie jest mniejsze. Jednakże tendencja ta, mimo że przewidywalna, uwzględnia również pojemność elektryczną akumulatorów (możliwości gromadzenia energii). Analiza energii ładowania akumulatorów przedstawiona na rys. 18 wskazuje, że jej zwiększenie nie zawsze jest związane ze zwiększeniem stopnia SOC.

Duży stopień naładowania akumulatorów skutkuje niewielkimi zmianami w ich ładowaniu podczas całego testu UDC. Końcowe wartości energii ładowania podczas dużego początkowego SOC zawierają się w granicach 60-100 W·h. Dla wszystkich pojazdów (przy dużym początkowym SOC) znaczny udział energii ładowania przypada na hamowanie odzyskujące (dla pojazdu Toyota Prius + silnik spalinowy nie został załączony w całym teście UDC, więc 100\% zgromadzonej energii stanowiła ta, którą odzyskano podczas hamowania). Energia ładowania dla początkowego minimalnego SOC akumulatorów pojazdów wynosiła 180-290 W·h. Wartości powyżej $250 \mathrm{~W} \cdot \mathrm{h}$ uzyskano dla pojazdów Prius plug-in oraz Prius + . Wartości odzyskiwanej energii są tym większe, im początkowy stopień naładowania akumulatorów jest mniejszy. Sterownik układu napędowego dąży do szybkiego doładowania akumulatorów przy wykorzystaniu silnika spalinowego jako generatora.

Analiza rysunku 18 pozwala na stwierdzenie, że wartości odzyskanej energii hamowania nie zależą od początkowego stopnia naładowania akumulatorów. Wartości te są zbliżone i charakterystyczne dla danego pojazdu w teście UDC i wynoszą (dane z dwóch przejazdów przy różnym początkowym SOC): dla pojazdu Toyota Prius plug-in $67 \mathrm{~W} \cdot \mathrm{h}$ i $54 \mathrm{~W} \cdot \mathrm{h}$, dla pojazdu Toyota Prius $+54 \mathrm{~W} \cdot \mathrm{h}$ i $48 \mathrm{~W} \cdot \mathrm{h}$ oraz dla Toyoty Auris 29 i $28 \mathrm{~W} \cdot \mathrm{h}$.

Zwiększenie energii ładowania przy mniejszym SOC spowodowane było odmiennym trybem sterowania układem napędowym. Na rysunku 19 przedstawiono wybrany fragment testu, na którym obserwowane jest wydłużenie czasu pracy silnika spalinowego oraz zwiększona prędkość obrotowa. Wydłużenie czasu pracy z około $8 \mathrm{~s}$ do $28 \mathrm{~s}$ umożliwiło odzyskanie przez układ 10-krotnie większej energii (z 4 do $43 \mathrm{~W} \cdot \mathrm{h}$ ). Zwiększenie natomiast prędkości obrotowej z 1300 do 1700-2000 obr/min skutkowało dwukrotnym zwiększeniem odzyskiwanej energii $\mathrm{z} 7 \mathrm{~W} \cdot \mathrm{h}$ do $14 \mathrm{~W} \cdot \mathrm{h}$.

Zmniejszenie udziału czasu pracy silnika spalinowego w teście UDC wynika częściowo z możliwości odzyskiwana energii kinetycznej podczas hamowania pojazdu. Warunki takie występują przez około $74 \mathrm{~s}$ testu UDC (po zsumowaniu wszystkich czterech elementarnych cykli ECE R15 testu), co stanowi około 9\% czasu trwania testu UDC. Dla badanych pojazdów dokonano obliczeń odzyskiwanej energii przy założeniach, że przyrost prędkości jest ujemny (hamowanie pojazdem) oraz silnik spalinowy jest wyłączony (przy włączonym silniku nie można określić wielkości energii odzyskanej z energii kinetycznej, gdyż nie jest znana wartość energii wytworzonej w generatorze napędzanym przez silnik spalinowy). 
High charge level of batteries causes insignificant changes in their charging during the entire UDC drive test. Final values of the recharging energy for the initially high SOC fall within the range from $60-100 \mathrm{~W} \cdot \mathrm{h}$. For all the vehicles (with high initial SOC) a significant share of the recharging energy falls within the energy recovering braking (for the Toyota Prius+ vehicle the combustion engine was not activated during the entire UDC test, thus $100 \%$ of the accumulated energy was the energy recovered during braking). The recharging energy for the initial minimal SOC for the vehicle batteries amounted to $180-290 \mathrm{~W} \cdot \mathrm{h}$. The values above $250 \mathrm{~W} \cdot \mathrm{h}$ were obtained for Prius plug-in and Prius + vehicles. Energy recovery is thus the higher the lower is the initial charge level of the battery. The drive system controller aims at fast recharging of batteries with the use of the combustion engine as a generator.

The analysis of Fig. 18 shows that the values of recovered braking energy do not depend on the initial charge level of the battery. These values are similar and characteristic for a given vehicle in the UDC drive test and amount to, respectively (data from two runs for different initial SOC): $67 \mathrm{~W} \cdot \mathrm{h}$ and $54 \mathrm{~W} \cdot \mathrm{h}$ for Toyota Prius plug-in, $54 \mathrm{~W} \cdot \mathrm{h}$ and $48 \mathrm{~W} \cdot \mathrm{h}$ for Toyota Prius + and 29 and $28 \mathrm{~W} \cdot \mathrm{h}$ for Toyota Auris.

Increase of the recharging energy for smaller SOC was caused by different mode of controlling the drive system. Figure 19 shows the selected part of the test, in which the prolonged combustion engine operation and increased engine speed are observed. Prolonging the operation time from $8 \mathrm{~s}$ to $28 \mathrm{~s}$ allowed the system recovery of 10 times more energy (from 4 to $43 \mathrm{~W} \cdot \mathrm{h}$ ). Increase of the engine speed from 1300 to 1700-2000 rpm caused, on the other hand, twofold increase in the energy recovered (from $7 \mathrm{~W} \cdot \mathrm{h}$ to $14 \mathrm{~W} \cdot \mathrm{h}$ ).

Reduction of the share of operation time of combustion engine in the UDC test ensues partially from the ability of recovering the kinetic energy during vehicle braking. Such conditions last for about $74 \mathrm{~s}$ of the UDC drive test (after summing up all four elementary ECE R15 cycles of the test), which constitutes approximately $9 \%$ of the duration time of the UDC drive test. For the tested vehicles the recovered energy was calculated, assuming that the vehicle speed decelerates (vehicle braking) and the combustion engine is deactivated (for the activated combustion engine it is impossible to determine the amount of the energy recovery from kinetic energy, as the value of the energy generated in the generator driven by the combustion engine is not known).

Figure 20 shows narrowed range of analysis presenting the difference between high-voltage battery recharging by combustion engine during the accelerating and the value of the kinetic energy recovered during the vehicle braking. Differences in the operation time of combustion engine during acceleration indicate an increased value of battery charging $-19 \mathrm{~W} \cdot \mathrm{h}$ for the initial $\mathrm{SOC}=40 \%$ compared to 8 $\mathrm{W} \cdot \mathrm{h}$ for $\mathrm{SOC}=70 \%$. This means obtaining an increased load and increased value of the combustion engine speed for the reduced SOC. Toyota Prius + vehicle braking is characterised

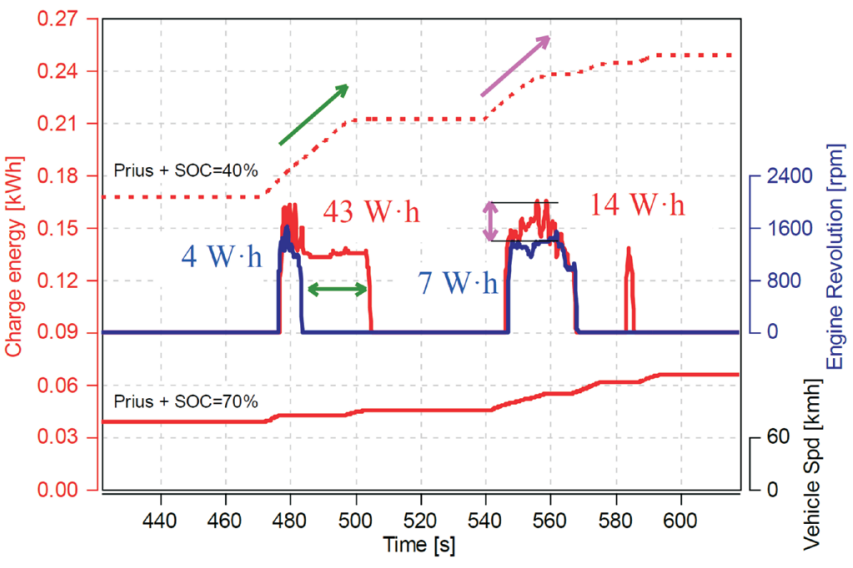

Fig. 19. Analysis of recharging the high-voltage accumulator with the use of different variants of combustion engine operation

Rys. 19. Analiza procesu ładowania akumulatorów wysokonapięciowych przy różnych wariantach pracy silnika spalinowego

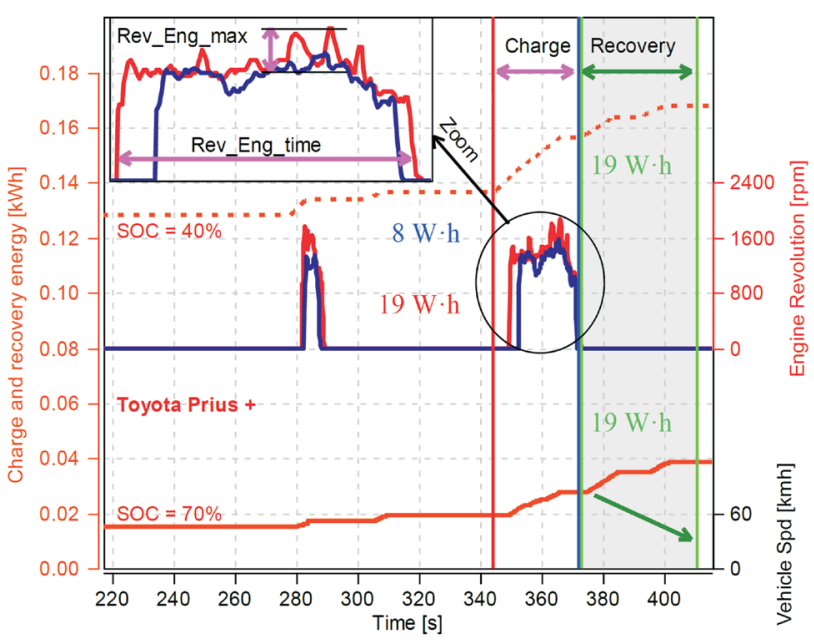

Fig. 20. The division of the energy recovered into the energy from the combustion engine and energy recovered during braking

Rys. 20. Podział odzyskiwanej energii na ładowanie silnikiem spalinowym i rekuperacje podczas hamowania

Przedstawiony na rysunku 20 zawężony zakres analizy przedstawia różnicę między ładowaniem akumulatorów wysokonapięciowych przez silnik spalinowy podczas zwiększania prędkości oraz wartości odzyskiwanej energii kinetycznej pojazdu podczas hamowania. Różnice w czasie pracy silnika spalinowego podczas przyspieszania wskazuja na zwiększoną wartość ładowania akumulatorów - $19 \mathrm{~W} \cdot \mathrm{h}$ przy początkowym $\mathrm{SOC}=40 \% \mathrm{w}$ porównaniu do $8 \mathrm{~W} \cdot \mathrm{h}$ przy SOC $=70 \%$. Oznacza to uzyskiwanie zwiększonego obciążenia i zwiększonej wartości prędkości obrotowej silnika spalinowego przy mniejszym SOC. Fragment hamowania pojazdem Toyota Prius + charakteryzuje się stałą wartością odzyskanej energii na poziomie $11 \mathrm{~W} \cdot \mathrm{h}$ (zmniejszanie prędkości od $50 \mathrm{~km} / \mathrm{h}$ do zera w czasie $37 \mathrm{~s}$ ), niezależnie od początkowego stopnia naładowania akumulatorów.

\section{Wnioski}

Warunki pracy nowoczesnych układów napędu hybrydowego zależą od wskaźników operacyjnych silników 
by constant value of the energy recovered at the level of 11 $\mathrm{W} \cdot \mathrm{h}$ (reduction of the speed from $50 \mathrm{kph}$ to zero in $37 \mathrm{~s}$ ) regardless of the initial charge level of the batteries.

\section{Conclusions}

Conditions of operation of the modern hybrid drive systems depend on the performance parameters of combustion engines, electric motors and their batteries. Currently the most important component of the vehicle with the hybrid drive system is its battery: on its capacity depends the strategy of controlling the system.

The conducted tests allow formulation of the following conclusions:

a) increase of the capacity of the battery significantly improves the distance travelled by a vehicle in the electric mode; high initial charge level of battery enabled covering the test run in the UDC test entirely in the electric mode.

b) low charge level of the battery increases the share of operation time of combustion engine in the UDC test; an increase of the initial charge level of battery by $10 \%$ reduces the combustion engine operation time to approximately $60 \mathrm{~s}$ (for Toyota Prius + and Toyota Auris) and to approximately $30 \mathrm{~s}$ for Toyota Prius plug-in (which is associated with higher electric capacity of the battery).

c) the dependency between the travelled distance of the test run in the electric mode and the charge level of battery was established (Fig. 21); this indicates that every $10 \%$ increase of the initial charge level of battery increases the distance travelled in this mode by $258 \mathrm{~m}$;

d) the values of the recovered braking energy do not depend on the initial charge level of the battery; these values are similar and characteristic for a given vehicle in the UDC drive test; these values amount to, respectively (data from two runs for different initial SOC): $67 \mathrm{~W} \cdot \mathrm{h}$ and $54 \mathrm{~W} \cdot \mathrm{h}$ for Toyota Prius plug-in, $54 \mathrm{~W} \cdot \mathrm{h}$ and $48 \mathrm{~W} \cdot \mathrm{h}$ for Toyota Prius + and 29 and $28 \mathrm{~W} \cdot \mathrm{h}$ for Toyota Auris.

The obtained dependencies allow for conclusion that the charge level of the battery can comprise the basis for determination of:

- the distance travelled by the vehicle in the electric mode in the UDC drive test; the error value for those calculations does not exceed $1 \mathrm{~m}$,

- the share of combustion engine operation time in the drive test.

The presented studies indicate importance of the conducted works concerning the processes of charging and discharging the high-voltage batteries for determining the actual efficiency of the hybrid drive systems. spalinowych, silników elektrycznych oraz akumulatorów tych pojazdów. Obecnie najważniejszym elementem pojazdu hybrydowego jest jego akumulator i od jego pojemności elektrycznej zależy strategia sterowania układem.

Przeprowadzone badania pozwalają na sformułowanie następujących wniosków:

a) zwiększenie pojemności akumulatora znacznie zwiększa zasięg pojazdu hybrydowego w trybie elektrycznym; duży stopień początkowego naładowania akumulatora pozwala na przejazd testu UDC całkowicie w trybie elektrycznym,

b) mały stopień naładowania akumulatora zwiększa czas pracy silnika spalinowego w teście UDC; początkowe zwiększenie stopnia naładowania akumulatora o 10\% zmniejsza czas pracy silnika spalinowego o około $60 \mathrm{~s}$ (dla Toyoty Prius + oraz Toyoty Auris) oraz o około $30 \mathrm{~s}$ dla Toyoty Prius plug-in (wynika to z większej pojemności elektrycznej akumulatorów),

c) uzyskano stałą zależność długości testu przebytego w trybie elektrycznym od stopnia naładowania akumulatorów (rys. 21); wskazuje ona, że każde 10-procentowe zwiększenie początkowego stopnia naładowania akumulatora zwiększa odcinek drogi przebyty w tym trybie o $258 \mathrm{~m}$,

d) wartości odzyskanej energii hamowania nie zależą od początkowego stopnia naładowania akumulatorów - są one zbliżone i charakterystyczne dla danego pojazdu w teście UDC; wartości te wynoszą (dane z dwóch przejazdów przy różnym początkowym SOC): dla pojazdu Toyota Prius plug-in $67 \mathrm{~W} \cdot \mathrm{h}$ i $54 \mathrm{~W} \cdot \mathrm{h}$, dla pojazdu Toyota Prius ${ }^{+}$ $54 \mathrm{~W} \cdot \mathrm{h}$ i $48 \mathrm{~W} \cdot \mathrm{h}$ oraz dla Toyoty Auris $29 \mathrm{i} 28 \mathrm{~W} \cdot \mathrm{h}$.

Uzyskane zależności pozwalają na stwierdzenie, że stopień naładowania akumulatorów może stanowić podstawę wyznaczenia:

- zasięgu pojazdu w trybie elektrycznym w teście UDC; wielkość błędu tych obliczeń dla badanych pojazdów nie przekracza $1 \mathrm{~m}$,

- udziału czasu pracy silnika spalinowego w teście jezdnym.

Przedstawione badania wskazują na istotność prowadzonych prac dotyczących procesów ładowania i rozładowywania akumulatorów wysokonapięciowych w celu określenia rzeczywistej efektywności układów napędu hybrydowego.

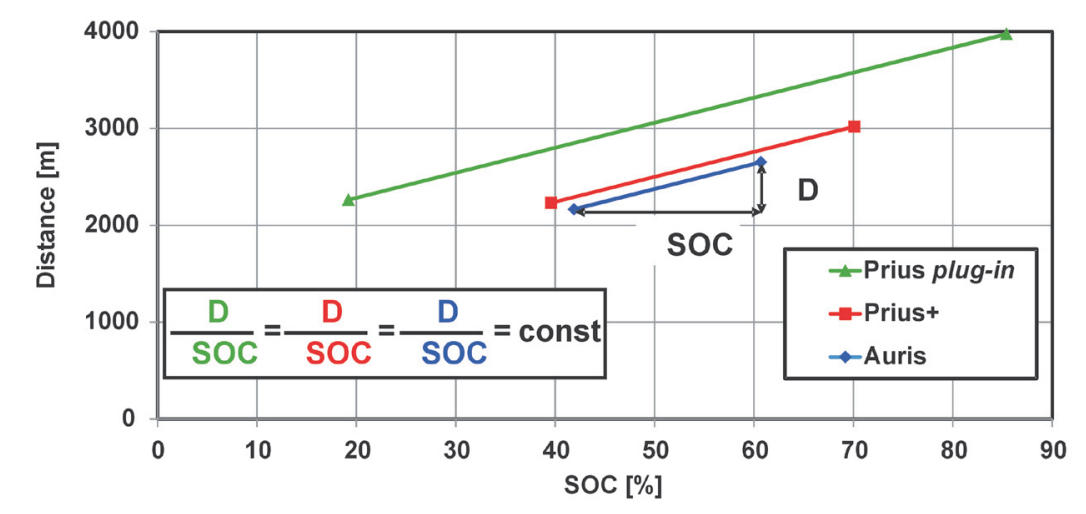

Fig. 21. The dependency between the distances travelled in the UDC drive test in the electric mode and the charge level of battery of the tested vehicles

Rys. 21. Zależność pokonanej drogi testu UDC w trybie elektrycznym od stopnia naładowania akumulatorów badanych pojazdów 


\section{Definitions/Oznaczenia}

EV electric vehicle/tryb elektryczny napędu

HDS hybrid synergy drive/układ napędu hybrydowego firmy Toyota

HV hybrid vehicle/tryb napędu hybrydowego

$\mathrm{n} \quad$ engine speed/prędkość obrotowa silnika spalinowego

NEDC new european driving cycle/nowy europejski test jezdny
nMG2 motor/generator2 speed/prędkość obrotowa silnika elektrycznego $M G 2$

nMG1 motor/generator1 speed/prędkość obrotowa generatora MG1

SOC state of charge/stopień naładowania akumulatorów

UDC urban driving cycle/test miejski

Vveh vehicle speed/prędkość pojazdu
This article was financially supported within the project "Engineer of the Future. Improving the didactic potential of the Poznan University of Technology" - POKL.04.03.00-00259/12, implemented within the Human Capital Operational Programme, co-financed by the European Union within the European Social Fund.
Publikacja powstała w ramach realizacji projektu "Inżynier przyszłości. Wzmocnienie potencjału dydaktycznego Politechniki Poznańskiej", nr POKL.04.03.00-00-259/12, współfinansowanego ze środków Unii Europejskiej w ramach Europejskiego Funduszu Społecznego.

\section{Bibliography/Bibliografia}

[1] Barlow T.J., Latham S., McCrae I.S., Boulter P.G. A reference book of driving cycles for use in the measurement of road vehicle emissions. Transport Research Laboratory, Berkshire 2009.

[2] Cieślik W., Pielecha I. Thermodynamic indexes of Atkinson cycle combustion engine operation under simulated traffic conditions. Journal of Mechanical and Transport Engineering Vol. 66 No. 1, 2014, 5-17, ISSN 2300-3596.

[3] Cieślik W., Pielecha I., Szałek A., Vanhaelst R. Wpływ naładowania akumulatorów na parametry pracy napędu hybrydowego plug-in w rzeczywistych warunkach ruchu. Logistyka 6/2014, 2796-2805, ISSN 1231-5478.

[4] European vehicle market statistics. Pocketbook 2013. www. theicct. org/sites/default/files/publications/EU vehiclemarket_pocketbook_2013_Web. pdf (dostęp z dnia 2.01.2015).

[5] JDPower. www.jjpower.com (dostęp $\mathrm{z}$ dnia 2.01.2015).

[6] Merkisz J., Pielecha J. Emisja cząstek stałych ze źródeł motoryzacyjnych. Wydawnictwo Politechniki Poznańskiej 2014.

[7] Merkisz J., Pielecha I., Radzimirski S. New trends in emission control in the European Union. Springer Tracts on Transportation and Traffic, Volume 4, New York, 2014, ISSN 2194 8119.

[8] Ohde B., Ślaski G. Modelowanie procesu rozładowywania akumulatora dla potrzeb symulacyjnego szacowania zasięgu samochodu elektrycznego. Logistyka 3/2014, 4777-4786, ISSN 1231-5478.
[9] Pielecha I., Cieślik W., Borowski P., Czajka J., Bueschke W. Reduction of the number of cylinders in internal combustion engines - contemporary trends in downsizing. Combustion Engines. 2014, 159(4), 12-25. ISSN 2300-9896.

[10] Pielecha I., Cieślik W., Czajka J., Borowski P., Bueschke W. The development of combustion engines for hybrid drive systems. Combustion Engines. 2014, 158(3), 23-35. ISSN 2300-9896.

[11] Pielecha I., Czajka J., Wisłocki K., Borowski P., Cieślik W. Wpływ stopnia naładowania akumulatorów na warunki pracy napędu hybrydowego w teście NEDC. Technika Transportu Szynowego 10/2013, 1261-1269, ISSN 1232-3829.

[12] Toyota Motor Poland Ltd. Sp. z o.o. www.toyota.pl (dostęp $z$ dnia 20.01.2015).

[13] www.epa.gov/nvfel/testing/dynamometer.htm (dostęp z dnia 19.01.2015)

[14] www.toyota-global.com (dostęp z dnia 19.01.2015).

[15] www.toyota-tech.eu (dostęp z dnia 19.01.2015).

Wojciech Cieślik, MEng. - postgraduate at the Faculty of Machines and Transportation of Poznan University of Technology.

Mgr inż. Wojciech Cieślik - doktorant na Wydziale Maszyn Roboczych i Transportu Politechniki Poznańskiej.

e-mail:wojciech.m.cieslik@doctorate.put.poznan.pl

Andrzej Szałek, DEng. - technical instructor in Toyota and Lexus Academy in Toyota Motor Poland Company Sp. z o. o. in Warsaw.

Drinż. Andrzej Szatek - wykładowca Akademii Toyoty i Lexusa w Toyota Motor Poland Company Sp. z o. o. Warszawa.

e-mail:andrzej.szalek@toyota.com.pl 